\title{
Heterotrophic Photo Fermentative Hydrogen Production
}

\author{
Ru Ying Li and Herbert H. P. Fang* \\ Department of Civil Engineering, The University of Hong Kong \\ Pokfulam Road, Hong Kong
}

Fax: 852-2559-5337; email: hrechef@hkucc.hku.hk

\begin{abstract}
This article reviews the state-of-the-art of heterotrophic photo fermentative hydrogen production, an infantile technology for wastewater treatment. Five tables were compiled from data scattered in literature, including bacteria strain, substrate, reactor design, maximum volumetric and specific production rates $\left(\mathrm{ml}-\mathrm{H}_{2} / \mathrm{l} / \mathrm{h}\right.$ and $/$ or $\mathrm{ml}-\mathrm{H}_{2} / \mathrm{g}$ VSS/h), yield as compared to stoichiometry (\%), culture volume $(\mathrm{ml})$, cell density (gVSS/l), light source and intensity $\left(\mathrm{W} / \mathrm{m}^{2}\right.$ or klux). Operational parameters discussed include light source and light intensity, $\mathrm{pH}$, temperature, substrates, nitrogen source, trace metal elements, inhibitors, and reactor design, followed by a discussion on the outlook of this technology.
\end{abstract}

KEY WORDS: hydrogen, fermentation, heterotrophic, phototrophic, wastewater. 


\section{INTRODUCTION}

Despite their detrimental effects on air pollution and global warming, fossil fuels are still the main source of energy supply for the world economy even though their reserves are depleting rapidly. This has led to the search for alternative energy sources, among which hydrogen has attracted much attention recently. Hydrogen has an energy yield of $122 \mathrm{~kJ} / \mathrm{g}$, about 2.75 times higher than those of hydrocarbons (Kapdan and Kargi, 2006), and may be used directly for combustion or generating electricity by fuel cells. It is an ideal fuel from the environment point of view, producing only water as by-product in the energy producing process. Many have predicted that hydrogen may become the main source of energy for the $21^{\text {th }}$ century economy (Rifkin, 2002).

Hydrogen is conventionally produced by either electrolysis of water or thermocatalytic reformation of hydrocarbons. Heterotrophic microbiological production of hydrogen has, however, attracted research interests due to its potential ability of degrading organic pollutants (Yetis et al., 2000; Li and Fang, 2007). Microbial production of hydrogen is often classified into two categories depending on whether light is required: dark fermentation and photo fermentation (Levin et al., 2004). Dark fermentation may, due to thermodynamic limitation, convert no more than $40 \%$ of the chemical energy in the organic pollutants into hydrogen in the absence of light, producing organic acids, mainly acetate and butyrate, and alcohols as by-products. Photo-fermentation may, on the other hand, potentially be able to convert acids and alcohols, which are the by-products of dark fermentation, into hydrogen using light as energy source. The latter process produces little organic 
residues and thus is potentially applicable for wastewater treatment (Das and Veziroğlu, 2001).

Unlike methanogenic fermentation, which has been commercialized for wastewater treatment for two decades with thousands of full-scale installation worldwide (Fang and Liu, 2002), fermentation of wastewater for hydrogen production remains at the infantile stage. Most of related studies were conducted using dark fermentation, as summarized in a recent review article ( $\mathrm{Li}$ and Fang, 2007). Studies of photo fermentative wastewater treatment were conducted mostly for suspended pure cultures using single substrates, with a few exceptions for mixed cultures and multi-substrate.

This article aims to review the enzymatic reactions of heterotrophic photo fermentative hydrogen production and the state-of-the-art of this infantile technology for wastewater treatment. Five tables were at first compiled for photo fermentative hydrogen production data scattered in literature, including bacteria strain, substrate, reactor design (batch or continuous), maximum volumetric and specific production rates $\left(\mathrm{ml}-\mathrm{H}_{2} / \mathrm{l} / \mathrm{h}\right.$ and/or $\left.\mathrm{ml}-\mathrm{H}_{2} / \mathrm{g}-\mathrm{VSS} / \mathrm{h}\right)$, yield as compared to stoichiometry (\%), culture volume (ml), cell density (g-VSS/l), light source and intensity (W/m² or klux). Table 1 was compiled for data on suspended growth of pure cultures, Table 2 for suspended growth of mixed cultures, Table 3 for combined photo-fermentative culture and others, Table 4 for immobilized cultures, and Table 5 for mutated cultures.

\section{ENZYMATIC REACTIONS OF PHOTO FERMENTATIVE HYDROGEN PRODUCTION}


Heterotrophic photo fermentative hydrogen production by purple non-sulfur bacteria is catalyzed by nitrogenase (Das and Veziroğlu, 2001; Melis and Melnicki, 2006). In the presence of molecular nitrogen $\left(\mathrm{N}_{2}\right)$, this enzyme which is composed of two proteins, i.e. dinitrogenase and dinitrogenase reductase (Burris, 1991; Orme-Johnson, 1992), reduces $\mathrm{N}_{2}$ into ammonium $\left(\mathrm{NH}_{4}{ }^{+}\right)$, as follows (Peters et al., 1995):

$$
\mathrm{N}_{2}+8 \mathrm{e}^{-}+10 \mathrm{H}^{+}+16 \mathrm{MgATP} \longrightarrow 2 \mathrm{NH}_{4}^{+}+\mathrm{H}_{2}+16 \mathrm{MgADP}+16 \mathrm{Pi}
$$

where Pi represents orthophosphate. However, in the absence of $\mathrm{N}_{2}$, nitrogenase may catalyze the following reaction resulting in the production of hydrogen:

$$
8 \mathrm{e}^{-}+8 \mathrm{H}^{+}+16 \mathrm{MgATP} \longrightarrow 4 \mathrm{H}_{2}+16 \mathrm{MgADP}+16 \mathrm{Pi}
$$

All phototrophic hydrogen-producing bacteria have a nitrogenase consisting of a cofactor (encoded by the gene nif) made of iron (Fe) and molybdenum (Mo) (Smith, 2002), including Rhodobacter sphaeroides (Haaker et al., 1982), Rhodobacter capsulatus (Siemann et al., 2001), Rhodospirillum rubrum (Ludden and Burris, 1978) and Rhodopseudomonas palustris (Arp and Zumft, 1983). Three species, i.e. R. capsulatus (Schneider et al., 1991; Gollan et al., 1993; Siemann et al., 2002), R. rubrum (Lehman and Roberts, 1991) and R. palustris (Zumft and Gastillo, 1978; Larimer et al., 2003), have additional nitrogenases (Eady and Leigh, 1994) consisting of cofactors made of FeFe (encoded by gene anf; Chisnell et al., 1988) and/or FeV (encoded by the gene vnf; Hales et al., 1986). Genes vnf and anf are activated only under Mo-limiting condition. 


\section{HETEROTROPHIC PHOTO FERMENTATIVE HYDROGEN- PRODUCING BACTERIA AND SLUDGE}

Phototrophic bacteria are mainly classified into two categories, i.e. purple bacteria and green bacteria, excluding several isolates without clear taxonomic position (Sasikala and Ramana, 1995). Each category may be further divided into sulfur and non-sulfur bacteria. Among the four groups, only the purple non-sulfur bacteria, which carry out anoxygenic photosynthesis using simple organic acids and sugars as substrate, are potentially useful for wastewater treatment. For the remaining groups, purple sulfur bacteria and green sulfur bacteria are autotrophic, using sulfide or elemental sulfur as electron donor, and thus are of little interest to environmental engineers for biological wastewater treatment. For the green non-sulfur bacteria, only one species, i.e. Chloroflexus aurantiacus (Gogotov et al., 1991), is known to be able to produce hydrogen.

Purple non-sulfur bacteria are heterotrophic and thus may be useful for the removal of organic pollutants in water. Those capable of producing hydrogen from organic substrates include the fresh water species $R$. sphaeroides (Fascetti et al., 1998), $R$. capsulatus (Ooshima et al., 1998), R. palustris (Oh et al., 2004) and R. rubrum (Najafpour et al., 2004), and the marine species Rhodovulum sp. (Yamada et al., 1998; Matsunaga et al., 2000), Rhodovulum sulfidophilum (Maeda et al., 2003), and Rhodobacter marinus (Yamada et al., 1996). 


\section{III.A. Pure Cultures}

Most studies of heterotrophic photo fermentative hydrogen production were conducted for pure cultures. Results compiled in Table 1 show that most studies were conducted using fresh water species, particularly $R$. sphaeroides and $R$. capsulatus. The rate of hydrogen production varied drastically, from 1.0 to $713.0 \mathrm{ml} / \mathrm{l} / \mathrm{h}$ or 0.7 to $250.0 \mathrm{ml} / \mathrm{g} / \mathrm{h}$, depending on the bacteria species, substrates, and operation conditions. The highest volumetric rate of $713 \mathrm{ml} / \mathrm{l} / \mathrm{h}$ was achieved by Rhodovulum sp. using malate (Matsunaga et al., 2000), and the highest specific rate of $250 \mathrm{ml} / \mathrm{l} / \mathrm{h}$ by $R$. sphaeroides from glucose (Zhu et al., 2001).

For $R$. sphaeroides, the highest hydrogen production rate, $240.0 \mathrm{ml} / \mathrm{l} / \mathrm{h}(171 \mathrm{ml} / \mathrm{g} / \mathrm{h})$ was achieved by strain RV using lactate in batch experiment (Nakada et al., 1995). Such a relatively high rate could be attributed to the high light intensity $\left(720 \mathrm{~W} / \mathrm{m}^{2}\right)$, or the reactor design (flat with a thickness of $0.5 \mathrm{~cm}$ ), or its small scale $(30 \mathrm{ml})$. For comparison, using the same bacteria treating a wastewater from sugar refinery mixed with malate in a continuous reactor had a substantially lower hydrogen production rate $(1.0 \mathrm{ml} / \mathrm{l} / \mathrm{h}$ or $0.71 \mathrm{ml} / \mathrm{g} / \mathrm{h})$ (Yetis et al., 2000).

For $R$. capsulatus, the hydrogen production rates varied from 12.5 to $75.0 \mathrm{ml} / \mathrm{l} / \mathrm{h}$ or 19.1 to $130.0 \mathrm{ml} / \mathrm{g} / \mathrm{h}$. In a continuous reactor, $R$. capsulatus produced hydrogen at the rates of 12.5-21.0 ml/1/h and 33.0-38.9 ml/g/h using mixed organic acids (Shi and $\mathrm{Yu}$, 2006). The highest volumetric and specific rates were from the degradation of lactate (Hillmer and Gest, 1977a; 1977b). 
For R. palustris, the hydrogen production rates varied from 1.6 to $24.9 \mathrm{ml} / \mathrm{l} / \mathrm{h}$ or 2.5 to $82.7 \mathrm{ml} / \mathrm{g} / \mathrm{h}$. The highest volumetric rate of $24.9 \mathrm{ml} / \mathrm{l} / \mathrm{h}$ was achieved using butyrate (Chen et al., 2007), and the specific rate of $82.7 \mathrm{ml} / \mathrm{g} / \mathrm{h}$ from lactate (Barbosa et al., 2001). R. palustris R1 was unable to produce hydrogen from butyrate (Barbosa et al., 2001).

R. rubrum was able to produce hydrogen from organic acids, such as lactate (Zürrer and Bachofen, 1979) and malate (Miyake et al., 1982), as well as CO (Klasson et al., 1993; Najafpour et al., 2004). In addition to the aforementioned four bacteria, Rubrivivax gelatinosus (Maness and Weaver, 2002; Mérida et al., 2004) was also found able to produce hydrogen from $\mathrm{CO}$ and carbohydrates. Using starch as substrate, the phototrophic hydrogen production rates by $R$. gelatinosus were $7.8-11.3 \mathrm{ml} / \mathrm{l} / \mathrm{h}$ and 7.0-17.0 ml/g/h (Mahakhan et al., 2005).

Table 1 also shows that several marine species are able to produce hydrogen from organic acids, sugars and PHB (poly- $\beta$-hydroxybutyrate). Among them, Rhodovulum sp. NKPB160471R had the highest hydrogen production rate up to $713.0 \mathrm{ml} / \mathrm{l} / \mathrm{h}$ from malate using a high light intensity of $1800 \mathrm{~W} / \mathrm{m}^{2}$ (Matsunaga et al. 2000). Other marine species produced hydrogen at rates ranging 3.0-68.6 ml/1/h (Ike et al., 1999; Kawaguchi et al., 2002; Maeda et al., 2003).

\section{III.B. Mixed Cultures}

Table 2 shows that very little information has been reported on hydrogen production by mixed cultures of phototrophic bacteria. Most of the hydrogen production rates ranged 4-10 $\mathrm{ml} / \mathrm{l} / \mathrm{h}$, with a noticeable exception of $20.3 \mathrm{ml} / \mathrm{l} / \mathrm{h}$ achieved using lactate 
as substrate by a mixed sludge, in which only one phototrophic bacteria strain, $R$. marinum A-501 (99\% similarity) was isolated (Ike et al., 1999). All cases in Table 2 were conducted in batch reactors with only one exception using a continuous reactor, in which a high rate of $17.4 \mathrm{ml} / \mathrm{l} / \mathrm{h}$ was achieved (Zhang et al., 2002).

\section{III.C. Co-cultures}

Most phototrophic hydrogen-producing (PHP) bacteria use simple organic acids and sugars as substrate. Producing hydrogen from complex organic pollutants in municipal, agricultural and industrial wastewaters may require co-cultures of dark and photo fermentative bacteria. The former converts complex organic pollutants into acids and sugars, which subsequently become substrates to the latter for hydrogen production. Some of these dark fermentative bacteria may either be hydrogen producers, such as Clostridium butyricum (Zhu et al., 2001), and non-hydrogen producers, such as Cellulomonas (Odom and Wall, 1983), Vibrio fluvialis (Ike et al., 1999) and Lactobacillus amylovorus (Kawaguchi et al., 2001). Table 3 lists the parameters in hydrogen production by various co-cultures.

Studies have also been conducted for other kinds of bacteria to form co-cultures with PHP bacteria. Halobacterium salinarum produces protons upon illumination for PHP bacteria, resulting in an increase of hydrogen production by 4-6 folds (Zabut et al., 2006). Vibrio fluvialis T-522 was able to induce hydrogen production by $R$. marinum A-501 from acetic acid and ethanol via an unknown mechanism (Ike et al., 1999). Some co-culture may result in the increase of light conversion efficiency in hydrogen production (Kondo et al., 2002b) 


\section{III.D. Immobilized Cultures}

A number of studies were conducted for immobilized PHP bacteria which may have several advantages over suspended bacteria, such as increasing cell density in the reactor, reducing washout, improving effluent quality (Tsygankov, 2001) and protecting cells from toxicity, such as $\mathrm{NH}_{4}{ }^{+}$and heavy metals (Zhu et al., 2001).

Table 4 summarizes parameters of hydrogen production by immobilized cultures of PHP bacteria as in Tables 1-3, plus additional information such as the media and maximum hydrogen production rate based on irradiation area $\left(\mathrm{ml} / \mathrm{cm}^{2} / \mathrm{h}\right)$. Of all the tested media, agar and alginate gels were most common for cell entrapment. The hydrogen production rates ranged $0.14-0.35 \mathrm{ml} / \mathrm{cm}^{2} / \mathrm{h}$, and the volumetric rates were $50.0-127.0 \mathrm{ml} / \mathrm{l} / \mathrm{h}$. The specific rates of $140-696 \mathrm{ml} / \mathrm{g} / \mathrm{h}$ for the immobilized cells by agar are much higher than the $0.7-250.0 \mathrm{ml} / \mathrm{g} / \mathrm{h}$ reported for suspended cultures (Table 1). Adding other ingredients into the media might produce various effects: cationic polymer alleviated the inhibitory effect of $\mathrm{NH}_{4}{ }^{+}$and chitosan increased hydrogen production rate by $20-30 \%$ (Zhu et al., 1999b). The main drawback of gels is that substrate needs to diffuse through the gel matrix, resulting in a decrease of the hydrogen production rate.

Porous glass (Tsygankov et al., 1994) and polyurethane form (Fedorov et al. 1998) have also been used as the support media for PHP bacteria. They are in chemically stable, inert to microorganisms, and transparent to light. The hydrogen production rates of $210-310 \mathrm{ml} / \mathrm{l} / \mathrm{h}$ by these media were much higher than the $1-75 \mathrm{ml} / \mathrm{l} / \mathrm{h}$ for most of the suspended cultures (Table 1) and the 50-127 ml/1/h for the PHP bacteria immobilized by agar or alginate. 


\section{III.E. Genetically Modified Cultures}

A number of studies have been conducted for hydrogen production by genetically modified cultures. Results in Table 5 show that genetically removing uptake hydrogenase from $R$. capsulatus could increase its hydrogen production by $30-100 \%$ (Krahn et al., 1996; Ooshima et al., 1998; Kim et al., 2004), and mutating the light harvesting system of $R$. sphaeroides $\mathrm{P} 3$ might increase the hydrogen production rate by $50-150 \%$ (Vasilyeva et al., 1999; Kondo et al., 2002a).

\section{SUBSTRATES}

Production of hydrogen from organic acids and sugars may be expressed as follows:

$$
\mathrm{C}_{\mathrm{a}} \mathrm{H}_{\mathrm{b}} \mathrm{O}_{\mathrm{c}}+(2 \mathrm{a}-\mathrm{c}) \mathrm{H}_{2} \mathrm{O} \longrightarrow \mathrm{a} \mathrm{CO}_{2}+(2 \mathrm{a}-\mathrm{c}+0.5 \mathrm{~b}) \mathrm{H}_{2}
$$

The efficiency of such process is often expressed by the ratio between the actual amount of hydrogen produced and the stoichiometric amount determined from Equation (3).

Results in Tables 1-5 show that most studies of photo-hydrogen production were conducted in batch reactors using organic acids as single substrate, including lactate, malate, acetate, butyrate, and even aromatic acids such as benzoate, cinnamate, mandelate, and benzoylformate (Fißler et al., 1995). Among the tested substrates, lactate and malate had better hydrogen yield than other acids. Using lactate as substrate, hydrogen yields of over $80 \%$ were achieved by suspended $R$. capsulatus 
IR3 (He et al., 2005) and by $R$. sphaeroides GL-1 immobilized in polyurethane foam (Fedorov et al., 1998). Using malate as substrate, a yield of $68 \%$ was reported for $R$. capsulatus ST410 (Ooshima et al., 1998). Yields were generally lower using acetate and butyrate as substrate, likely due to the formation of intracellular PHB (Koku et al., 2002) which competed with hydrogen for electrons (Khatipov et al., 1998). Most of the yields from acetate and butyrate by the suspended pure cultures ranged only 820\% (Table 1). R. palustris P4 (Oh et al., 2004) and Rhodopseudomonas sp. HCC2037 (Barbosa et al., 2001) had yields of about 70\% from acetate, whereas $R$. palustris R1 could not produce hydrogen from butyrate (Barbosa et al., 2001). Yields of about $67 \%$ were also reported for acetate and butyrate by immobilized cultures (Mao et al., 1986).

Results in Tables 1-5 show that carbohydrates, such as glucose, sucrose, starch and cellobiose, had yields in general below $10 \%$.

A few studies were conducted using mixed acids as substrate or treating the acids-rich effluent of dark fermentation. Using pure cultures, hydrogen yields ranging $33-46 \%$ were obtained by suspended cells with hydrogen production rates ranging 12.5-21.0 $\mathrm{ml} / \mathrm{l} / \mathrm{h}$ (Shi and $\mathrm{Yu}, 2005$ and 2006). Higher hydrogen yields (53-64\%) and production rates $(79-115 \mathrm{ml} / \mathrm{l} / \mathrm{h})$ were achieved using immobilized pure cultures (Mao et al., 1986). Using mixed cultures, the yield ranged 12-22\% (Zhang et al., 2002; Takabatake et al., 2004).

Several attempts were made to produce hydrogen by photo fermentation from actual wastewaters. Rates of hydrogen production were low (1-6 ml/l/h) when tested against 
sugar refinery wastewater (Yiğit et al., 1999; Yetis et al., 2000) and olive mill wastewater (Eroğlu et al., 2004). Higher rates were obtained (respectively, 14.9 and $78.8 \mathrm{ml} / \mathrm{l} / \mathrm{h}$ ) treating a tofu wastewater by a suspended co-culture of $R$. sphaeroides and Clostridium butyricum (Zhu et al., 2002), and by immobilized R. sphaeroides (Zhu et al., 1999a).

\section{OPERATIONAL PARAMETERS}

Several operational parameters are crucial to the optimal production of hydrogen, including light source and light intensity, $\mathrm{pH}$, temperature, substrates, nitrogen source, trace metal elements, and inhibitors.

\section{V.A. Light Source and Light Intensity}

Most of photo fermentative hydrogen production used light with a wavelength in the range of 400-950 nm (Akkerman et al., 2002). Various light sources have been used, including simulated sunlight (Wakayama et al., 1998), tungsten lamp (Nakada et al., 1995; Fascetti et al., 1998; Zhu et al., 2001), halogen lamp (Barbosa et al., 2001; Kim et al., 2004), and fluorescent lamp (Matsunaga et al., 2000). Some used monochromatic light by specific filters (Takabatake et al., 2004).

Light intensity may be measured by either $\mathrm{W} / \mathrm{m}^{2}$ or lux. The conversion between the two units varies substantially, depending on the wavelength of light (Neumann et al., 2003). Without knowing the specific wavelength, one may assume $1 \mathrm{~W} / \mathrm{m}^{2}$ is equivalent to 30-100 lux (Nakada et al., 1995; Ooshima et al., 1998; Ko and Noike, 
2002). Most of the studies in Tables 1-5 used light intensity in the range of 100-300 $\mathrm{W} / \mathrm{m}^{2}$ (or 6-10 klux).

The reported optimum light intensity varied among species and even among strains of the same species. In general, the optimum light intensity was in the range of 30-100 $\mathrm{W} / \mathrm{m}^{2}$ or 5-8 klux. The reported optimum light intensities were $5 \mathrm{klux}$ for $R$. sphaeroides O.U.001 (Sasikala et al., 1991), 28-32 W/m² for R. sphaeroides KD131 (Kim et al., 2006), $30 \mathrm{~W} / \mathrm{m}^{2}$ or more for Rhodovulum sp. (Matsunaga et al., 2000), 3 klux (35 W/m² given by the author) for R. capsulatus ST410 (Ooshima et al., 1998), and 6-8 klux for R. palustris (Yang et al., 2002).

High intensity of light may inhibit hydrogen production for some bacteria. The inhibitory intensities were reported as $400 \mathrm{~W} / \mathrm{m}^{2}$ for $R$. sphaeroides KD131 (Kim et al., 2006), and 9 klux for R. palustris (Yang et al., 2002). However, light intensities as high as $1800 \mathrm{~W} / \mathrm{m}^{2}$ did not cause any inhibitory effect for Rhodovulum sp. (Matsunaga et al., 2000), and 10 klux for R. sphaeroides O.U.001 (Sasikala et al., 1991).

The reported photo efficiency, which is percentage of photo energy radiated onto the reactor being utilized for the formation of hydrogen, was mostly below $10 \%$. This is one of the drawbacks needs to be overcome for the further development of photo fermentative hydrogen production, unless the free sunlight is used. In a few exceptional cases, higher photo efficiencies (up to 35\%) were achieved when using low intensity light (13-45 W/m²) (Akkerman et al. 2002). However, at such level of light intensity, hydrogen was produced at unrealistic rates about $90 \%$ lower than those 
under the normal intensity of $1800 \mathrm{~W} / \mathrm{m}^{2}$.

In addition, the illumination pattern also affected hydrogen production by some PHP bacteria. Koku et al. (2003) found that more hydrogen was produced in reactors which were illuminated in on-off cycles, simulating the day-night pattern of solar radiation, than those under continuous illumination.

\section{V.B. $\mathrm{pH}$}

The reported optimum $\mathrm{pH}$ varied among species: $\mathrm{pH} 7.2$ for $R$. sphaeroides VM81 (Margaritis and Vogrinetz, 1983), pH 7.0-7.5 for R. sphaeroides O.U.001 (Sasikala et al., 1991; Sasikala et al., 1995), pH 7.4-7.6 for $R$. sphaeroides KD131 (Kim et al., 2004; Kim et al., 2006), and $\mathrm{pH}$ 8.5-9.0 for R. capsulatus, (Tsygankov and Laurinavichene, 1996). The reported optimal $\mathrm{pH}$ for mixed cultures were substrate dependent: $\mathrm{pH}$ 7.0-8.0 for acetate, and $\mathrm{pH}$ 8.0-9.0 for butyrate (Fang et al., 2005).

\section{V.C. Temperature}

Reported data showed that $30-40^{\circ} \mathrm{C}$ is in general the optimum range of temperature. The reported optimum ranges were $30-40^{\circ} \mathrm{C}$ for R. sphaeroides O.U.001 (Sasikala et al., 1991), $30-37^{\circ} \mathrm{C}$ for $R$. palustris (Yang et al., 2002), and $30^{\circ} \mathrm{C}$ for $R$. capsulatus (He et al., 2006).

\section{V.D. Substrates}

Effects of substrates concentration were studied mainly for organic acids. Using malate as substrate, the optimum concentrations were $30 \mathrm{mM}$ for $R$. sphaeroides O.U.001 (Sasikala et al., 1991), and $60 \mathrm{mM}$ for R. capsulatus ST410 (Ooshima et al., 
1998). Using lactate, the hydrogen production rate increased with concentration up to $50 \mathrm{mM}$ for R. sphaeroides O.U.001 (Sasikala et al., 1991). Using acetate, the optimum concentrations were 30-50 mM for R. palustris (Yang et al., 2002) but hydrogen production was repressed completely at $100 \mathrm{mM}$ of acetate. While another strain $R$. palustris $\mathrm{P} 4$ achieved similar rate and yield regardless of the acetate concentrations in the range of $12-55 \mathrm{mM}$ (Oh et al., 2004). The optimum concentration of $11 \mathrm{mM}$ was reported for a mixed phototrophic sludge using butyrate (Fang et al., 2005), and $39 \mathrm{mM}$ of glucose for R. sphaeroides VM81 (Margaritis and Vogrinetz, 1983). Using benzoate as substrate, the optimum concentration was 3.0 mM for immobilized R. palustris (Fißler et al., 1995).

Substrates used for cell cultivation may also affect hydrogen production. Hillmer and Gest (1977b) found that $R$. capsulatus grown on $\mathrm{C}_{4}$ dicarboxylic acids (i.e. malate, fumarate, and succinate) were able to produce hydrogen from these acids as well as lactate and pyruvate, but those grown on lactate, pyruvate or glycerol could not produce hydrogen from $\mathrm{C}_{4}$ dicarboxylic acids.

\section{V.E. Trace Metal Elements}

Since photo heterotrophic hydrogen production is catalyzed by nitrogenase, which consists of a cofactor made of iron (Fe) and molybdenum (Mo), the availability of these two elements is of great significance. Hydrogenase in PHP bacteria is generally accepted as the metabolic antagonist of nitrogenase, assuming to function in the direction of hydrogen uptake (Koku et al., 2002). Nickel is necessary for the synthesis of hydrogenase (Doyle and Arp, 1988), implying that the presence of nickel may promote the hydrogenase synthesis and therefore inhibit hydrogen production. 
Stimulation of phototrophic hydrogen production by the addition of $\mathrm{Mo}^{6+}$ and $\mathrm{Fe}^{2+}$ has been demonstrated by many studies (Kim et al., 1980; Krahn et al., 1996; Fascetti et al., 1998). The $\mathrm{Mo}^{6+}$ and $\mathrm{Fe}^{2+}$ concentrations commonly used for hydrogen production are $0.3 \mathrm{mg} / 1$ and $2.4 \mathrm{mg} / \mathrm{l}$, respectively, as originally suggested by Ormerod et al. (1961) for R. rubrum. Studies on the concentration effect of $\mathrm{Mo}^{6+}$ and $\mathrm{Fe}^{2+}$ are still very limited. Kars et al. (2006) found that R. sphaeroides O.U.001 produced most hydrogen at $1.6 \mathrm{mg} / \mathrm{l} \mathrm{Mo}^{6+}$ and $5.6 \mathrm{mg} / \mathrm{F} \mathrm{Fe}^{2+}$, and yet Lee and $\mathrm{Yu}$ (2005) found hydrogen production by $R$. palustris WP3-5 was independent of $\mathrm{Mo}^{6+}$ concentration. Yang et al. (2002) found that $\mathrm{Fe}^{3+}$ at $2.8 \mathrm{mg} / \mathrm{l}$ was optimal for hydrogen production by R. palustris, but significantly inhibited hydrogen production at $6.7 \mathrm{mg} / \mathrm{l}$. Yang et al. (2002) also found that $\mathrm{Ni}^{2+}$ at $0.2-0.4 \mathrm{mg} / 1$ repressed hydrogen production completely.

\section{V.F. Nitrogen Sources}

Although $\mathrm{NH}_{4}{ }^{+}$is the common $\mathrm{N}$ source for fermentation, it inhibits nitrogenase activity and thus cannot be used for phototrophic hydrogen production. An early study (Hillmer and Gest, 1977a) found that R. capsulatus favored glutamate, serine, and alanine among the 19 tested amino acids, as $\mathrm{N}$ source for hydrogen production. However, glutamate has remained as the most common source of N. Sasikala et al. (1995) found that high N/C ratios (2/3 or above) would completely inhibit hydrogen production due to the accumulation of $\mathrm{NH}_{4}{ }^{+}$released from deamination of amino acids. The N/C ratio in feed solution in most studies was kept below 0.18 , as used by Hillmer and Gest (1977a). On the other hand, Eroğlu et al. (1999) compared the hydrogen production by $R$. sphaeroides using glutamate and malate as $\mathrm{N}$ and $\mathrm{C}$ 
sources, and found the optimal $\mathrm{N}: \mathrm{C}$ ratio was 0.03 (corresponding to a molar malate:glutamate ratio of 15:2).

\section{V.G. Inhibitors}

Molecular $\mathrm{O}_{2}$ and $\mathrm{N}_{2}$, as well as $\mathrm{NH}_{4}{ }^{+}$, are known inhibiters to phototrophic hydrogen production. Molecular $\mathrm{O}_{2}$ adversely affects the nitrogenase activity and thus hydrogen production as found by Ooshima et al. (1998) for the Rhodovulum sp. and by Matsunaga et al. (2000) for $R$. capsulatus. The presence of $1-4 \%$ of $\mathrm{O}_{2}$ reduced hydrogen production by $50 \%$ for two strains of $R$. capsulatus (Krahn et al., 1996). However, Koku (2002) found that such effect was irreversible for $R$. sphaeroides, whereas Hochman and Burris (1981) and Goldberg et al. (1987) found the effect reversible for $R$. capsulatus and $R$. rubrum, and for $R$. sphaeroides, respectively.

The presence of molecular $\mathrm{N}_{2}$ inhibits the hydrogen formation enzymatic activity of nitrogenase (Ooshima et al., 1998). However, such an inhibitory effect seems to be reversible. Ormerod et al. (1961) found that hydrogen production by R. rubrum was completely inhibited by $\mathrm{N}_{2}$, but the activity was fully recovered once $\mathrm{N}_{2}$ was replaced by helium.

Ionic $\mathrm{NH}_{4}^{+}$may stimulate hydrogen production activity in trace amounts but may cause inhibition at higher concentrations. Hydrogen production by the suspended culture of Rhodopseudomonas sp. from acetate was stimulated by $1 \mathrm{mM} \mathrm{NH}_{4}^{+}$, but was inhibited by $50 \%$ with $5 \mathrm{mM} \mathrm{NH}_{4}^{+}$and $100 \%$ with $15 \mathrm{mM} \mathrm{NH}_{4}^{+}$(Hoekema et al., 2002); however, such an inhibition effect appeared also to be reversible. Zhu et al. (2001) found that hydrogen production by the suspended culture of $R$. sphaeroides 
RV using lactate was repressed $50 \%$ at $10 \mathrm{mM}$ of $\mathrm{NH}_{4}{ }^{+}$, whereas the immobilized $R$. sphaeroides had the highest hydrogen production with $5 \mathrm{mM} \mathrm{NH}_{4}^{+}$and was not inhibited by $\mathrm{NH}_{4}^{+}$at $10 \mathrm{mM}$ (Zhu et al., 1999b). This suggests that immobilized cells are more resistant to the toxicity of $\mathrm{NH}_{4}^{+}$.

\section{REACTOR DESIGN}

The key design concern is to maximize the surface-volume ratio of the reactor for uniform illumination (Ogbonna and Tanaka, 2001). Most studies on photo hydrogen production were conducted in laboratory scale in batches using either tubes (Margaritis and Vogrinetz, 1983), serum bottles (Fang et al., 2005), flat flasks (Zhu et al., 2001), water-jacketed columns (Eroğlu et al., 1999), or plate reactors (Kondo et al., 2002b; Kondo et al., 2006). A novel design using optical fibers to transmit light from an external source was demonstrated recently (Chen et al., 2006).

Continuous photobioreactors in columned and spherical configurations have been used for hydrogen production. These reactors were generally equipped with a water jacket for temperature control and operated in the complete-mix mode (Yetis et al., 2000; Zhang et al., 2002; Shi and Yu, 2006).

\section{OUTLOOK}

Although the technical feasibility of producing hydrogen from organic substrates by photo fermentation has been demonstrated, the development of this technology is still at its infantile stage. Large scale production of hydrogen from wastewater using 
sunlight as source of photo energy is still a remote target. Based on the review for over 100 related papers, it is obvious that some aspects are crucial for the further development of this technology and warrant further studies. Firstly, further research should be carried out using mixed cultures from environmental samples treating mixed substrates. Secondly, reactor designs should be improved for better capture of light, and operational parameters, such as the HRT, $\mathrm{pH}$, and substrates concentration, should be further optimized. Thirdly, photo hydrogen production under daily on-off illumination of sunlight should be examined. And lastly, further studies should be conducted to combine dark and photo fermentations into a single package for hydrogen production from wastewater.

\section{ACKNOWLEDGEMENTS}

The authors wish to thank the Hong Kong Research Grants Council for the financial support of this study (HKU 7106/04E and 7129/05E), and Ru Ying Li wishes to thank RGC for the research assistantship and HKU for the postgraduate studentship.

\section{REFERENCES}

Akkerman, I., Janssen, M., Rocha, J., and Wijffels, R.H. Photobiological hydrogen production: photochemical efficiency and bioreactor design, Int. J. Hydrogen Energy 27, 1195-1208, 2002.

Arp, D.J., and Zumft, W.G. Overproduction of Nitrogenase by Nitrogen-Limited Cultures of Rhodopseudomonas palustris, J. Bacteriol. 153, 1322-1330, 1983. 
Barbosa, M.J., Rocha, J.M.S., Tramper, J., and Wijffels, R.H. Acetate as a carbon source for hydrogen production by photosynthetic bacteria, J. Biotechnol. 85, 25-33, 2001.

Burris, R.H. Nitrogenase, J. Biol. Chem. 266, 9339-9342, 1991.

Chen, C.Y., Lee, C.M., and Chang, J.S. Hydrogen production by indigenous photosynthetic bacterium Rhodopseudomonas palustris WP3-5 using optical fiber-illuminating photobioreactors, Biochem. Eng. J. 32, 33-42, 2006.

Chen, C.Y., Lu, W.B., Wu, J.F., and Chang, J.S. Enhancing phototrophic hydrogen production of Rhodopseudomonas palustris via statistical experimental design, Int. J. Hydrogen Energy 32, 940-949, 2007.

Chisnell, J.R., Premakumar, R., and Bishop, P.E. Purification of a $2^{\text {nd }}$ alternative nitrogenase from a nifHDK deletion strain of Azotobacter vinelandii, J. Bacteriol. 170, 27-33, 1988.

Das, D., and Veziroğlu, T.N. Hydrogen production by biological processes: a survey of literature, Int. J. Hydrogen Energy 26, 13-28, 2001.

Doyle, C.M., and Arp, D.J. Nickel affects expression of the nickel-containing hydrogenase of Alcaligenes latus, J. Bacteriol. 170, 3891-3896, 1988.

Eady, R.R., and Leigh, G.J. Metals in the nitrogenase, J. Chem. Soc. Dalton. Trans. 19, 2739-2747, 1994.

Eroğlu, E., Gündüz, U., Yücel, M., Türker, L., and Eroğlu, İ. Photobiological hydrogen production by using olive mill wastewater as a sole substrate source, Int. J. Hydrogen Energy 29, 163-171, 2004.

Eroğlu, İ., Aslan, K., Gündüz, U., Yücel, M., and Türker, L. Substrate consumption rates for hydrogen production by Rhodobacter sphaeroides in a column photobioreactor, J. Bacteriol. 70, 103-113, 1999. 
Fang, H.H.P., and Liu, H. Effect of $\mathrm{pH}$ on hydrogen production from glucose by a mixed culture, Bioresour. Technol. 82, 87-93, 2002.

Fang, H.H.P., Liu, H., and Zhang, T. Phototrophic hydrogen production from acetate and butyrate in wastewater, Int. J. Hydrogen Energy 30, 785-793, 2005.

Fascetti, E., D’ Addario, E., Todini, O., and Robertiello, A. Photosynthetic hydrogen evolution with volatile organic acids derived from the fermentation of source selected municipal solid wastes, Int. J. Hydrogen Energy 23, 753-760, 1998.

Fedorov, A.S., Tsygankov, A.A., Rao, K.K., and Hall, D.O. Hydrogen photoproduction by Rhodobacter sphaeroides immobilized on polyurethane foam, Biotechnol. Lett. 20, 1007-1009, 1998.

Fißler, J., Kohring, G.W., and Giffhorn, F. Enhanced hydrogen production from aromatic acids by immobilized cells of Rhodopseudomonas palustris, Appl. Microbiol. Biotechnol. 44, 43-46, 1995.

Gogotov, I.N., Zorin, N.A., and Serebriakova, L.T. Hydrogen production by model systems including hydrogenase from phototrophic bacteria, Int. J. Hydrogen Energy 16, 393-396, 1991.

Goldberg, I., Nadler, V., and Hochman, A. Mechanism of nitrogenase switch-off by oxygen, J. Bacteriol. 169, 874-879, 1987.

Gollan, U., Schneider, K., Muller, A., Schuddekopf, K., and Klipp, W. Detection of the in vivo incorporation of a metal cluster into a protein. The FeMo cofactor is inserted into the $\mathrm{FeFe}$ protein of the alternative nitrogenase of Rhodobacter capsulatus, Eur. J. Biochem. 215, 25-35, 1993.

Haaker, H., Laane, C., Hellingwerf, K., Houwer, B., Konings, W.N., and Veeger, C. Short-term regulation of the nitrogenase activity in Rhodopseudomonas sphaeroides, Eur. J. Biochem. 127, 639-645, 1982. 
Hales, B.J., Case, E.E., Morningstar, J.E., Dzeda, M.F., and Mauterer, L.A. Isolation of a new vanadium-containing nitrogenase from Azotobacter vinelandii, Biochemistry 25, 7251-7255, 1986.

He, D.L., Bultel, Y., Magnin, J.P., Roux, C., and Willison, J.C. Hydrogen photosynthesis by Rhodobacter capsulatus and its coupling to a PEM fuel cell, J. Power Sources 141, 19-23, 2005.

He, D.L., Bultel, Y., Magnin, J.P., and Willison, J.C. Kinetic analysis of photosynthetic growth and photohydrogen production of two strains of Rhodobacter capsulatus, Enzyme and Microbial Tech. 38, 253-259, 2006.

Hillmer, P., and Gest, H. $\mathrm{H}_{2}$ metabolism in the photosynthetic bacterium Rhodopseudomonas capsulata: $\mathrm{H}_{2}$ production by growing cultures, J. Bacteriol. 129, 724-731, 1977a.

Hillmer, P., and Gest, H. $\mathrm{H}_{2}$ metabolism in the photosynthetic bacterium Rhodopseudomonas capsulata: production and utilization of $\mathrm{H}_{2}$ by resting cells, J. Bacteriol. 129, 732-739, $1977 b$.

Hochman, A., and Burris, R.H. Effect of oxygen on acetylene reduction by photosynthetic bacteria, J. Bacteriol. 147, 492-499, 1981.

Hoekema, S., Bijmans, M., Janssen, M., Tramper, J., and Wijffels, R.H. A pneumatically agitated flat-panel photobioreactor with gas re-circulation: anaerobic photoheterotrophic cultivation of a purple non-sulfur bacterium, Int. J. Hydrogen Energy 27, 1331-1338, 2002.

Ike, A., Murakawa, T., Kawaguchi, H., Hirata, K., and Miyamoto, K. Photoproduction of hydrogen from raw starch using a halophilic bacterial community, J. Biosci. Bioeng. 88, 72-77, 1999. 
Kapdan, I.K., and Kargi, F. Bio-hydrogen production from waste materials, Enzyme and Microbial Technol. 38, 569-582, 2006.

Kars, G., Gündüz, U., Yücel, M., Türker, L., and Eroğlu, İ. Hydrogen production and transcriptional analysis of nifD, nifK and hupS genes in Rhodobacter sphaeroides O.U.001 grown in media with different concentrations of molybdenum and iron, Int. J. Hydrogen Energy 31, 1536-1544, 2006.

Katsuda, T., Arimoto, T., Igarashi, K., Azuma, M., Kato, J., Takakuwa, S., and Ooshima, H. Light intensity distribution in the externally illuminated cylindrical photo-bioreactor and its application to hydrogen production by Rhodobacter capsulatus, Biochem. Eng. J. 5, 157-164, 2000.

Kawaguchi, H., Hashimoto, K., Hirata, K., and Miyamoto, K. $\mathrm{H}_{2}$ production from algal biomass by a mixed culture of Rhodobium marinum A-501 and Lactobacillus amylovorus, J. Biosci. Bioeng. 91, 277-282, 2001.

Kawaguchi, H., Nagase, H., Hashimoto, K., Kimata, S., Doi, M., Hirata, K., and Miyamoto, K. Effect of algal extract on $\mathrm{H}_{2}$ production by a photosynthetic bacterium Rhodobium marinum A-501: analysis of stimulating effect using a kinetic model, J. Biosci. Bioeng. 94, 62-69, 2002.

Khatipov, E., Miyake, M., Miyake, J., and Asada, Y. Accumulation of poly- $\beta-$ hydroxybutyrate by Rhodobacter sphaeroides on various carbon and nitrogen substrates, FEMS Microbiol. Lett. 162, 39-45, 1998.

Kim, J.S., Ito, K., and Takahashi, H. The relationship between nitrogenase activity and hydrogen evolution in Rhodopseudomonas palustris, Agric. Biol. Chem. 44, 827-833, 1980. 
Kim, M.S., Ahn, J.H., and Yoon, Y.S. Photo-biological hydrogen production by the uptakehydrogenase and PHB synthase deficient mutant of Rhodobacter sphaeroides, In: Biohydrogen III, Miyake, J. Eds., p45-55, 2004.

Kim, M.S., Baek, J.S., and Lee, J.K. Comparison of $\mathrm{H}_{2}$ accumulation by Rhodobacter sphaeroides KD 131 and its uptake hydrogenase and PHB synthase deficient mutant, Int. J. Hydrogen Energy 31, 121-127, 2006.

Klasson, K.T., Lundbäck, K.M.O., Clausen, E.C., and Gaddy, J.L. Kinetics of light limited growth and biological hydrogen production from carbon monoxide and water by Rhodospirillum rubrum, J. Biotech. 29, 177-188, 1993.

Ko, I.B., and Noike, T. Use of blue optical filters for suppression of growth of algae in hydrogen producing non-axenic cultures of Rhodobacter sphaeroides RV, Int. J. Hydrogen Energy 27, 1297-1302, 2002.

Koku, H., Eroğlu, İ., Gündüz, U., Yücel, M., and Türker, L. Aspects of the metabolism of hydrogen production by Rhodobacter sphaeroides, Int. J. Hydrogen Energy 27, 1315-1329, 2002.

Koku, H., Eroğlu, İ., Gündüz, U., Yücel, M., and Türker, L. Kinetics of biological hydrogen production by the photosynthetic bacterium Rhodobacter sphaeroides O.U.001, Int. J. Hydrogen Energy 28, 381-388, 2003.

Kondo, T., Arakawa, M., Hirai, T., Wakayama, T., Hara, M., and Miyake, J. Enhancement of hydrogen production by a photosynthetic bacterium mutant with reduced pigment, J. Biosci. Bioeng. 93, 145-150, 2002a.

Kondo, T., Arakawa, M., Wakayama, T., and Miyake, J. Hydrogen production by combining two types of photosynthetic bacteria with different characteristics, Int. J. Hydrogen Energy 27, 1303-1308, $2002 b$. 
Kondo, T., Wakayama, T., and Miyake, J. Efficient hydrogen production using a multi-layered photobioreactor and a photosynthetic bacterium mutant with reduced pigment, Int. J. Hydrogen Energy 31, 1522-1526, 2006.

Krahn, E., Schneider, K., and Muller, A. Comparative characterization of $\mathrm{H}_{2}$ production by the conventional Mo nitrogenase and the alternative "iron-only" nitrogenase of Rhodobacter capsulatus hup mutants, Appl. Microbiol, Biotechnol. 46, 285-290, 1996.

Larimer, F.W., Chain, P., Hauser, L., Lamerdin, J., Malfatti, S., Do, L., Land, M.L., Pelletier, D.A., Beatty, J.T., Lang, A.S., Tabita, F.B., Gibson, J.L., Hanson, T.E., Bobst, C., Torres, J.L.T., Peres, C., Harrison, F.H., Gibson, J., and Harwood, C.S. Complete genome sequence of the metabolically versatile photosynthetic bacterium Rhodopseudomonas palustris, Nature Biotechnol. 22, 55-61, 2004.

Lee, C.M., and Yu, K.M. Limiting factors of photohydrogen production by Rhodopseudomonas palustris WP3-5, International Conference on Environmental, Industrial and Applied Microbiology, Badajoz, Spain, March 2005.

Lehman, L.J., and Roberts, G.P. Identification of an alternative nitrogenase system in Rhodospirillum rubrum, J. Bacteriol. 173, 5705-5711, 1991.

Levin, D.B., Pitt, L., and Love, M. Biohydrogen production: prospects and limitations to practical application, Int. J. Hydrogen Energy 29, 173-185, 2004.

Li, C.L., and Fang, H.H.P. Fermentative hydrogen production from wastewater and solid wastes by mixed cultures, Crit. Rev. Environ. Sci. Technol. 37, 1-39, 2007.

Ludden, P.W., and Burris, R.H. Purification and properties of nitrogenase from Rhodospirillum rubrum, and evidence for phosphate, ribose and an adenine-like unit covalently bound to the iron protein, Biochem. J. 175, 251-259, 1978. 
Maeda, I., Miyasaka, H., Umeda, F., Kawase, M., and Yagi, K. Maximization of hydrogen production ability in high-density suspension of Rhodovulum sulfidophilum cells using intracellular poly (3-hydroxybutyrate) as sole substrate, Biotechnol. Bioeng. 81, 474-481, 2003.

Mahakhan, P., Chobvijuk, C., Ngmjarearnwong, M., Trakulnalermsai, S., Bucke, C., Svasti, J., Kanlayakrit, W., and Chitradon, L. Molecular hydrogen production by a thermotolerant Rubrivivax gelatinosus using raw cassava starch as an electron donor, ScienceAsia 31, 415-424, 2005.

Maness, P.C., and Weaver, P.F. Hydrogen production from a carbon-monoxide oxidation pathway in Rubrivivax gelatinosus, Int. J. Hydrogen Energy 27, 1407$1411,2002$.

Mao, X.Y., Miyake, J., and Kawamura, S. Screening photosynthetic bacteria for hydrogen production from organic acids, J. Ferment. Technol. 64, 245-249, 1986.

Margaritis, A., and Vogrinetz, J. The effect of glucose concentration and $\mathrm{pH}$ on hydrogen production by Rhodopseudomonas sphaeroides VM 81, Int. J. Hydrogen Energy 8, 281-284, 1983.

Matsunaga, T., Hatano, T., Yamada, A., and Matsumoto, M. Microaerobic hydrogen production by photosynthetic bacteria in a double-phase photobioreactor, Biotechnol. Bioeng. 68, 647-651, 2000.

Melis, A., and Melnicki, M.R. Integrated biological hydrogen production, Int. J. Hydrogen Energy 31, 1563-1573, 2006.

Mérida, W., Maness, P.C., Brown, R.C., and Levin, D.B. Enhanced hydrogen production from indirectly heated, gasified biomass, and removal of carbon gas 
emissions using a novel biological gas reformer, Int. J. Hydrogen Energy 29, 283-290, 2004.

Miyake, J., Tomizuka, N., and Kamibayashi, A. Prolonged photo-hydrogen production by Rhodospirillum rubrum, J. Ferment. Technol. 60, 199-203, 1982.

Najafpour, G., Younesi, H., and Mohamed, A.R. Effect of organic substrate on hydrogen production from synthesis gas using Rhodospirillum rubrum, in batch culture, Biochem. Eng. J. 21, 123-130, 2004.

Nakada, E., Asada, Y., Arai, T., and Miyake, J. Light penetration into cell suspensions of photosynthetic bacteria and relation to hydrogen production, J. Ferment. Bioeng. 80, 53-57, 1995.

Neumann, L., Castro, F., Neumann, A., and Sbert, M. Color appearance in multispectral radiosity, In: Proceedings on the $2^{\text {nd }}$ Hungarian Computergraphics and Geometry Conference, Szirmay-Kalos, L., and Renner, G. Eds., p183-194, 2003.

Odom, J.M., and Wall, J.D. Photoproduction of $\mathrm{H}_{2}$ from cellulose by an anaerobic bacterial coculture, Appl. Environ. Microbiol. 45, 1300-1305, 1983.

Ogbonna, J.C., and Tanaka, H. Photobioreactor design for photobiological production of hydrogen, In: Biohydrogen II, Miyake, J. Eds., p245-261, 2001.

Oh, Y.K., Seol, E.H., Kim, M.S., and Park, S. Photoproduction of hydrogen from acetate by a chemoheterotrophic bacterium Rhodopseudomonas palustris $\mathrm{P} 4$, Int. J. Hydrogen Energy 29, 1115-1121, 2004.

Ooshima, H., Takakuwa, S., Katsuda, T., Okuda, M., Shirasawa, T., Azuma, M., and Kato, J. Production of hydrogen by a hydrogenase-deficient mutant of Rhodobacter capsulatus, J. Ferment. and Bioeng. 85, 470-475, 1998. 
Orme-Johnson, W.H. Nitrogenase structure: where to now, Science 257 (5077), 16391640, 1992.

Ormerod, J.G., Ormerod, K.S., and Gest, H. Light-dependent utilization of organic compounds and photoproduction of molecular hydrogen by photosynthetic bacteria; relationships with nitrogen metabolism, Archives of Biochemistry and Biophysics 94, 449-463, 1961.

Peters, J.W., Fisher, K., and Dean, D.R. Nitrogenase structure and function: A biochemical-genetic perspective, Annu. Rev. Microbiol. 49, 335-366, 1995.

Rifkin, J. The Hydrogen Economy. Penguin Putnam Inc. New York. 2002.

Sasikala, C., and Ramana, C.V. Biotechnological potentials of anoxygenic phototrophic bacteria. I. Production of single-cell protein, vitamins, ubiquinones, hormones, and enzymes and use in wastewater treatment, Adv. Appl. Microbiol. 41, 173-226, 1995.

Sasikala, K., Ramana, C.V., and Rao, P.R. Environmental regulation for optimal biomass yield and photoproduction of hydrogen by Rhodobacter sphaeroides O.U.001, Int. J. Hydrogen Energy 16, 597-601, 1991.

Sasikala, C., Ramana, C.V., and Rao, P.R. Regulation of simultaneous hydrogen production during growth by $\mathrm{pH}$ and glutamate in Rhodobacter sphaeroides O.U.001, Int. J. Hydrogen Energy 20, 123-126, 1995.

Schneider, K., Muller, A., Schramm, V., and Klipp, W. Demonstration of a molybdenum-and vanadium-independent nitrogenase in a nifHDK-deletion mutant of Rhodobacter capsulatus, Eur. J. Biochem. 195, 653-661, 1991.

Shi, X.Y., and Yu, H.Q. Continuous production of hydrogen from mixed volatile fatty acids with Rhodopseudomonas capsulate, Int. J. Hydrogen Energy 31, 16411647, 2006. 
Shi, X.Y., and Yu, H.Q. Response surface analysis on the effect of cell concentration and light intensity on hydrogen production by Rhodopseudomonas capsulate, Process Biochem. 40, 2475-2481, 2005.

Siemann, S., Schneider, K., Behrens, K., Knöchel, A., Klipp, W., and Müller, A. FeMo cofactor biosynthesis in a nifE ${ }^{-}$mutant of Rhodobacter Capsulatus, Eur. J. Biochem. 268, 1940-1952, 2001.

Siemann, S., Schneider, K., Dröttboomt, M., and Müller, A. The Fe-only nitrogenase and the Mo nitrogenase from Rhodobacter capsulatus. A comparative study on the redox properties of the metal clusters present in the dinitrogenase components, Eur. J. Biochem. 269, 1650-1661, 2002.

Smith, B.E. Structure: Nitrogenase reveals its inner secrets, Science 297 (5587), 1654$1655,2002$.

Takabatake, H., Suzuki, K., Ko, I.B., and Noike, T. Characteristics of anaerobic ammonia removal by a mixed culture of hydrogen producing photosynthetic bacteria, Bioresource Technol. 95, 151-158, 2004.

Tsygankov, A.A. Hydrogen photoproduction by purple bacteria: immobilized vs. suspension cultures, In: Biohydrogen II, Miyake, J. Eds., p229-243, 2001.

Tsygankov, A.A., Hirata, Y., Miyake, M., Asada, Y., and Miyake, J. Photobioreactor with photosynthetic bacteria immobilized on porous-glass for hydrogen photoproduction, J. Ferm. Bioeng. 5, 575-578, 1994.

Tsygankov, A.A., and Laurinavichene, T.V. Dependence of growth and nitrogenase activity on the illumination and $\mathrm{pH}$ in Rhodobacter capsulatus with and without Mo, Microbiol 65, 436-441, 1996.

Vasilyeva, L., Miyake, M., Khatipov, E., Wakayama, T., Sekine, M., Hara, M., Nakada, E., Asada, Y., and Miyake, J. Enhanced hydrogen production by a 
mutant of Rhodobacter sphaeroides having an altered light-harvesting system, $J$. Biosci. Bioeng. 87, 619-624, 1999.

Wakayama, T., Toriyama, A., Kawasugi, T., Arai, T., Asada, Y., and Miyake, J. Photohydrogen production using photosynthetic bacterium Rhodobacter sphaeroides RV: simulation of the light cycle of natural sunlight using an artificial source, In: Biohydrogen, New York: Plenum, p375-455, 1998.

Yamada, A., Hatano, T., and Matsunaga, T. Conversion efficiencies of light energy to hydrogen by a novel Rhodovulum sp. and its uptake-hydrogen mutant, In: Biohydrogen, New York: Plenum, p167-170, 1998.

Yamada, A., Takano, H., Burgess, J.G., and Matsunaga, T. Enhanced hydrogen production by a marine photosynthetic bacterium, Rhodobacter marinus, immobilized onto light-diffusing optical fibers, J. Marine. Biotechnol. 4, 23- 27, 1996.

Yang, S.P., Wang, Z.W., Zhao, C.G., Qu, Y.B., and Qian, X.M. Generation of hydrogen from photolysis of organic acids by photosynthetic bacteria, Chinese Chemical Lett. 13, 1111-1114. 2002.

Yetis, M., Gündüz, U., Eroğlu, İ., Yücel, M., and Türker, L. Photoproduction of hydrogen from sugar refinery wastewater by Rhodobacter sphaeroides O.U.001, Int. J. Hydrogen Energy 25, 1035-1041, 2000.

Yiğit, D.Ö., Gündüz, U., Türker, L., Yücel, M., and Eroğlu, İ. Identification of byproducts in hydrogen producing bacteria; Rhodobacter sphaeroides O.U.001 grown in the waste water of a sugar refinery, J. Biotechnol. 70, 125-131, 1999.

Zabut, B., El-Kahlout, K., Yücel, M., Gündüz, U., Türker, L., and Eroğlu, İ. Hydrogen gas production by combined systems of Rhodobacter sphaeroides 
O.U.001 and Halobacterium salinarum in a photobioreactor, Int. J. Hydrogen Energy 31, 1553-1562, 2006.

Zhang, T., Liu, H., and Fang, H.H.P. Microbial analysis of a phototrophic sludge producing hydrogen from acidified wastewater, Biotechnol. Lett. 24, 1833-1837, 2002.

Zhu, H.G., Suzuki, T., Tsygankov, A.A., Asada, Y., and Miyake, J. Hydrogen production from tofu wastewater by Rhodobacter sphaeroides immobilized in agar gels, Int. J. Hydrogen Energy 24, 305-310, 1999a.

Zhu, H.G., Wakayama, T., Asada, Y., and Miyake, J. Hydrogen production by four cultures with participation by anoxygenic phototrophic bacterium and anaerobic bacterium in the presence of $\mathrm{NH}_{4}^{+}$, Int. J. Hydrogen Energy 26, 1149-1154, 2001.

Zhu, H.G., Wakayama, T., Suzuki, T., Asada, Y., and Miyake, J. Entrapment of Rhodobacter sphaeroides RV in cationic polymer/agar gels for hydrogen production in the presence of $\mathrm{NH}_{4}^{+}, \mathrm{J}$. Biosci. Bioeng. 88, 507-512, $1999 \mathrm{~b}$.

Zhu, H.G., Ueda, S., Asada, Y., and Miyake, J. Hydrogen production as a novel process of wastewater treatment - studies on tofu wastewater with entrapped $R$. sphaeroides and mutagenesis, Int. J. Hydrogen Energy 27, 1349-1357, 2002.

Zumft, W.G., and Castillo, F. Regulatory properties of the nitrogenase of Rhodopseudomonas palustris, Arch. Microbiol. 117, 53-60, 1978.

Zürrer, H., and Bachofen, R. Hydrogen production by the photosynthetic bacterium Rhodospirillum rubrum, Appl. Environ. Microbiol. 37, 789-793, 1979. 


\section{LIST OF TABLES}

Table 1. Hydrogen production by suspended cells of the pure culture of PHP bacteria

Table 2. Hydrogen production by suspended cells of the mixed culture of PHP bacteria

Table 3. Hydrogen production by co-culture of PHP bacteria with other bacteria

Table 4. Hydrogen production by immobilized cultures of PHP bacteria

Table 5. Hydrogen production by mutants of PHP bacteria 
Table 1. Hydrogen production by suspended cells of the pure culture of PHP bacteria

\begin{tabular}{|c|c|c|c|c|c|c|c|c|c|c|c|}
\hline \multirow[t]{2}{*}{ Microorganisms } & \multirow[t]{2}{*}{ Substrates } & \multirow[t]{2}{*}{$\begin{array}{l}\text { Reactor } \\
\text { type }\end{array}$} & \multirow[t]{2}{*}{$\begin{array}{l}\text { Max. } \mathrm{H}_{2} \\
\text { rate }(\mathrm{ml} / \mathrm{l} / \mathrm{h})\end{array}$} & \multirow{2}{*}{$\begin{array}{l}\operatorname{Max} . \mathrm{H}_{2} \\
\text { rate } \\
(\mathrm{ml} / \mathrm{g} / \mathrm{h})\end{array}$} & \multirow[t]{2}{*}{$\begin{array}{l}\text { Yield } \\
(\%)\end{array}$} & \multirow{2}{*}{$\begin{array}{l}\text { Culture } \\
\text { volume } \\
(\mathrm{ml})\end{array}$} & \multirow{2}{*}{$\begin{array}{l}\text { Cell } \\
\text { density } \\
(\mathrm{g} / \mathrm{l})\end{array}$} & \multirow[t]{2}{*}{ Light source } & \multicolumn{2}{|c|}{$\begin{array}{l}\text { Light } \\
\text { intensity }\end{array}$} & \multirow[t]{2}{*}{ Reference } \\
\hline & & & & & & & & & $\mathrm{W} / \mathrm{m}^{2}$ & klux & \\
\hline $\begin{array}{l}\text { R. sphaeroides } \\
\text { VM81 }\end{array}$ & Glucose & Batch & 2.2 & 3.5 & 3.5 & 11 & 0.64 & Incandescent & & 10 & $\begin{array}{l}\text { Margaritis } \\
\text { and } \\
\text { Vogrinetz, } \\
1983\end{array}$ \\
\hline R. sphaeroides RV & Lactate & Batch & 240.0 & 171.0 & 19.6 & 30 & $\begin{array}{l}1.30- \\
1.50\end{array}$ & Tungsten & 720 & 40 & $\begin{array}{l}\text { Nakada et } \\
\text { al., } 1995\end{array}$ \\
\hline R. sphaeroides RV & Lactate & Batch & - & - & - & 2 & 1.00 & $\begin{array}{l}\text { Halogen }(800 \\
\text { and } 850 \mathrm{~nm})\end{array}$ & 80 & & $\begin{array}{l}\text { Vasilyeva et } \\
\text { al., } 1999\end{array}$ \\
\hline R. sphaeroides RV & Glucose & Batch & 75.0 & 250.0 & 17.0 & 200 & 0.30 & Tungsten & & 8.5 & $\begin{array}{l}\text { Zhu et al., } \\
2001\end{array}$ \\
\hline R. sphaeroides RV & Lactate & Batch & 30 & 65.2 & 26.1 & 165 & 0.46 & Tungsten & 300 & & $\begin{array}{l}\text { Kondo et } \\
\text { al., } 2002 \mathrm{a}\end{array}$ \\
\hline R. sphaeroides RV & Lactate & Batch & 19.1 & 31.9 & - & 800 & 0.60 & Tungsten & 300 & & $\begin{array}{l}\text { Kondo et } \\
\text { al., } 2006\end{array}$ \\
\hline R. sphaeroides RV & $\begin{array}{l}\text { Acetate +propionate } \\
+ \text { butyrate }\end{array}$ & Batch & $\begin{array}{l}0.8 \mathrm{ml} / \mathrm{h} / \\
\text { vial }\end{array}$ & - & - & - & - & Incandescent & 165 & 5 & $\begin{array}{l}\text { Ko and } \\
\text { Noike, } 2002\end{array}$ \\
\hline R. sphaeroides RV & $\begin{array}{l}\text { VFAs from } \\
\text { fermentation of fruit } \\
\text { and vegetable } \\
\text { wastes }\end{array}$ & $\begin{array}{l}\text { Continuous } \\
\text { (HRT 25h) } \\
(8-10 \mathrm{~d})\end{array}$ & 48.0 & 100.0 & - & 1000 & 0.48 & Tungsten & & 10 & $\begin{array}{l}\text { Fascetti et } \\
\text { al., } 1998\end{array}$ \\
\hline $\begin{array}{l}\text { R. sphaeroides } \\
\text { O.U.001 }\end{array}$ & Malate & Batch & 12.0 & 2.4 & 42.4 & 400 & 5.00 & Tungsten & 200 & & $\begin{array}{l}\text { Eroğlu et } \\
\text { al., } 1999\end{array}$ \\
\hline $\begin{array}{l}\text { R. sphaeroides } \\
\text { O.U.001 }\end{array}$ & Malate & Batch & 8.0 & 10.0 & 36.0 & 400 & & Tungsten & $\begin{array}{l}150- \\
250\end{array}$ & & $\begin{array}{l}\text { Koku et al., } \\
2003\end{array}$ \\
\hline $\begin{array}{l}\text { R. sphaeroides } \\
\text { O.U.001 }\end{array}$ & $\begin{array}{l}\text { Sugar refinery } \\
\text { wastewater }\end{array}$ & Batch & 6.4 & - & - & 50 & - & N.S. & 200 & & $\begin{array}{l}\text { Yiğit et al., } \\
1999\end{array}$ \\
\hline $\begin{array}{l}\text { R. sphaeroides } \\
\text { O.U.001 }\end{array}$ & $\begin{array}{l}\text { Sugar refinery } \\
\text { wastewater }\end{array}$ & Batch & 3.8 & 0.9 & - & 150 & 4.40 & N.S. & 200 & & $\begin{array}{l}\text { Yetis et al., } \\
2000\end{array}$ \\
\hline
\end{tabular}




\begin{tabular}{|c|c|c|c|c|c|c|c|c|c|c|c|}
\hline $\begin{array}{l}\text { R. sphaeroides } \\
\text { O.U.001 }\end{array}$ & $\begin{array}{l}\text { Sugar refinery } \\
\text { wastewater }+ \text { malate }\end{array}$ & $\begin{array}{l}\text { Continuous } \\
\text { (HRT 80d) }\end{array}$ & 1.0 & 0.7 & - & 400 & 1.40 & N.S. & 200 & & $\begin{array}{l}\text { Yetis et al., } \\
2000\end{array}$ \\
\hline $\begin{array}{l}\text { R. sphaeroides } \\
\text { O.U.001 }\end{array}$ & $\begin{array}{l}\text { Sugar refinery } \\
\text { wastewater +malate }\end{array}$ & $\begin{array}{l}\text { Continuous } \\
\text { (HRT 32d) }\end{array}$ & 3.0 & 3.1 & - & 400 & 0.97 & N.S. & 200 & & $\begin{array}{l}\text { Yetis et al., } \\
2000\end{array}$ \\
\hline $\begin{array}{l}\text { R. sphaeroides } \\
\text { O.U.001 }\end{array}$ & $\begin{array}{l}\text { Olive mill } \\
\text { wastewater }\end{array}$ & Batch & 4.0 & 9.8 & - & 400 & 0.41 & Tungsten & 200 & & $\begin{array}{l}\text { Eroğlu et } \\
\text { al., } 2004\end{array}$ \\
\hline $\begin{array}{l}\text { R. sphaeroides } \\
\text { KD131 }\end{array}$ & Malate & Batch & 33.8 & - & 36.7 & 50 & $\begin{array}{l}3.1-3.4 \\
\mathrm{OD}_{660}\end{array}$ & Halogen & & 8 & $\begin{array}{l}\text { Kim et al., } \\
2004\end{array}$ \\
\hline $\begin{array}{l}\text { R. sphaeroides } \\
\text { KD131 }\end{array}$ & Lactate & Batch & 16.7 & - & 18.1 & 50 & $\begin{array}{l}2.8 \\
\mathrm{OD}_{660}\end{array}$ & Halogen & & 8 & $\begin{array}{l}\text { Kim et al., } \\
2004\end{array}$ \\
\hline $\begin{array}{l}\text { R. sphaeroides } \\
\text { KD131 }\end{array}$ & Acetate & Batch & 4.9 & - & 8.0 & 50 & $\begin{array}{l}3.1 \\
\mathrm{OD}_{660}\end{array}$ & Halogen & & 8 & $\begin{array}{l}\text { Kim et al., } \\
2004\end{array}$ \\
\hline $\begin{array}{l}\text { R. sphaeroides } \\
\text { KD131 }\end{array}$ & Glucose & Batch & 7.6 & - & 4.1 & 50 & $\begin{array}{l}3.64 \\
\mathrm{OD}_{660}\end{array}$ & Halogen & & 8 & $\begin{array}{l}\text { Kim et al., } \\
2004\end{array}$ \\
\hline R. capsulatus B10S & N.S. & Batch & 74.0 & - & - & 1 & $\begin{array}{l}2 \\
\mathrm{OD}_{600}\end{array}$ & N.S. & - & - & $\begin{array}{l}\text { Krahn et al., } \\
1996\end{array}$ \\
\hline R. capsulatus B100 & Malate & Batch & 37.7 & - & 25.0 & 5 & - & Tungsten & & 6 & $\begin{array}{l}\text { Ooshima et } \\
\text { al., } 1998\end{array}$ \\
\hline R. capsulatus B100 & Acetate & Batch & 26.2 & - & 53.0 & 5 & - & Tungsten & & 6 & $\begin{array}{l}\text { Ooshima et } \\
\text { al., } 1998\end{array}$ \\
\hline R. capsulatus IR3 & Lactate & Batch & 19.4 & 29.8 & 84.8 & 3000 & 0.65 & Incandescent & - & - & $\begin{array}{l}\text { He et al., } \\
2005\end{array}$ \\
\hline R. capsulatus IR3 & Lactate & Batch & 52.5 & 105.0 & 68.2 & 1000 & 0.50 & Incandescent & - & - & $\begin{array}{l}\text { He et al., } \\
2006\end{array}$ \\
\hline R. capsulatus JP91 & Lactate & Batch & 38.5 & 41.8 & 52.7 & 1000 & 0.92 & Incandescent & - & - & $\begin{array}{l}\text { He et al., } \\
2006\end{array}$ \\
\hline $\begin{array}{l}\text { R. capsulatus Z-1 } \\
\text { (Growing cells) }\end{array}$ & Glucose & Batch & - & 88.0 & 32.0 & 60 & $\begin{array}{l}0.4 \\
\mathrm{OD}_{660} \\
\end{array}$ & Incandescent & & 10.8 & $\begin{array}{l}\text { Hillmer and } \\
\text { Gest, } 1977 \mathrm{a}\end{array}$ \\
\hline $\begin{array}{l}\text { R. capsulatus Z-1 } \\
\text { (Growing cells) }\end{array}$ & Fructose & Batch & - & 100.0 & 27.0 & 60 & $\begin{array}{l}0.4 \\
\mathrm{OD}_{660} \\
\end{array}$ & Incandescent & & 10.8 & $\begin{array}{l}\text { Hillmer and } \\
\text { Gest, } 1977 \mathrm{a}\end{array}$ \\
\hline $\begin{array}{l}\text { R. capsulatus Z-1 } \\
\text { (Growing cells) }\end{array}$ & Sucrose & Batch & - & 60.0 & 6.0 & 60 & $\begin{array}{l}0.4 \\
\mathrm{OD}_{660} \\
\end{array}$ & Incandescent & & 10.8 & $\begin{array}{l}\text { Hillmer and } \\
\text { Gest, 1977a }\end{array}$ \\
\hline
\end{tabular}




\begin{tabular}{|c|c|c|c|c|c|c|c|c|c|c|c|}
\hline $\begin{array}{l}\text { R. capsulatus Z-1 } \\
\text { (Growing cells) }\end{array}$ & Lactate & Batch & - & 130.0 & 72.0 & 60 & $\begin{array}{l}0.4 \\
\mathrm{OD}_{660} \\
\end{array}$ & Incandescent & & 10.8 & $\begin{array}{l}\text { Hillmer and } \\
\text { Gest, 1977a } \\
\end{array}$ \\
\hline $\begin{array}{l}\text { R. capsulatus Z-1 } \\
\text { (Growing cells) }\end{array}$ & Pyruvate & Batch & - & 130.0 & 68.0 & 60 & $\begin{array}{l}0.4 \\
\mathrm{OD}_{660} \\
\end{array}$ & Incandescent & & 10.8 & $\begin{array}{l}\text { Hillmer and } \\
\text { Gest, 1977a } \\
\end{array}$ \\
\hline $\begin{array}{l}\text { R. capsulatus Z-1 } \\
\text { (Growing cells) }\end{array}$ & Malate & Batch & - & 90.0 & 56.0 & 60 & $\begin{array}{l}0.4 \\
\mathrm{OD}_{660} \\
\end{array}$ & Incandescent & & 10.8 & $\begin{array}{l}\text { Hillmer and } \\
\text { Gest, 1977a } \\
\end{array}$ \\
\hline $\begin{array}{l}\text { R. capsulatus Z-1 } \\
\text { (Growing cells) }\end{array}$ & Succinate & Batch & - & 100.0 & 72.0 & 60 & $\begin{array}{l}0.4 \\
\mathrm{OD}_{660} \\
\end{array}$ & Incandescent & & 10.8 & $\begin{array}{l}\text { Hillmer and } \\
\text { Gest, 1977a }\end{array}$ \\
\hline $\begin{array}{l}\text { R. capsulatus Z-1 } \\
\text { (Resting cells) }\end{array}$ & Lactate & Batch & 75.0 & 75.0 & - & 2.5 & $1.0-1.2$ & Incandescent & & 10.8 & $\begin{array}{l}\text { Hillmer and } \\
\text { Gest, } 1977 \mathrm{~b} \\
\end{array}$ \\
\hline $\begin{array}{l}\text { R. capsulatus Z-1 } \\
\text { (Resting cells) }\end{array}$ & Pyruvate & Batch & 41.0 & 41.0 & - & 2.5 & $1.0-1.2$ & Incandescent & & 10.8 & $\begin{array}{l}\text { Hillmer and } \\
\text { Gest, } 1977 \mathrm{~b}\end{array}$ \\
\hline $\begin{array}{l}\text { R. capsulatus Z-1 } \\
\text { (Resting cells) }\end{array}$ & Malate & Batch & 58.0 & 58.0 & - & 2.5 & $1.0-1.2$ & Incandescent & & 10.8 & $\begin{array}{l}\text { Hillmer and } \\
\text { Gest, } 1977 \mathrm{~b}\end{array}$ \\
\hline $\begin{array}{l}\text { R. capsulatus Z-1 } \\
\text { (Resting cells) }\end{array}$ & Fumarate & Batch & 25.0 & 25.0 & - & 2.5 & $1.0-1.2$ & Incandescent & & 10.8 & $\begin{array}{l}\text { Hillmer and } \\
\text { Gest, } 1977 \mathrm{~b}\end{array}$ \\
\hline $\begin{array}{l}\text { R. capsulatus Z-1 } \\
\text { (Resting cells) }\end{array}$ & Succinate & Batch & 71.0 & 71.0 & - & 2.5 & $1.0-1.2$ & Incandescent & & 10.8 & $\begin{array}{l}\text { Hillmer and } \\
\text { Gest, } 1977 \mathrm{~b}\end{array}$ \\
\hline R. capsulatus & $\begin{array}{l}\text { Acetate + propionate } \\
\text { +butyrate }\end{array}$ & Batch & 14.7 & 19.1 & 32.6 & 150 & 0.77 & N.S. & - & - & $\begin{array}{l}\text { Shi and } \mathrm{Yu} \text {, } \\
2005\end{array}$ \\
\hline R. capsulatus & Acetate +propionate & $\begin{array}{l}\text { Continuous } \\
\text { (HRT } 72 \mathrm{~h}) \\
(20 \mathrm{~d})\end{array}$ & 21.0 & 38.9 & 45.9 & 1500 & 0.54 & N.S. & - & - & $\begin{array}{l}\text { Shi and } \mathrm{Yu} \text {, } \\
2006\end{array}$ \\
\hline R. capsulatus & $\begin{array}{l}\text { Acetate + propionate } \\
+ \text { butyrate }\end{array}$ & $\begin{array}{l}\text { Continuous } \\
(\text { HRT } 72 \mathrm{~h}) \\
(10 \mathrm{~d})\end{array}$ & 17.0 & 37.8 & 45.0 & 1500 & 0.45 & N.S. & - & - & $\begin{array}{l}\text { Shi and } \mathrm{Yu} \text {, } \\
2006\end{array}$ \\
\hline R. capsulatus & $\begin{array}{l}\text { Effluent from } \\
\text { acidogenic } \mathrm{H}_{2} \\
\text { production reactor }\end{array}$ & $\begin{array}{l}\text { Continuous } \\
(\text { HRT } 72 \mathrm{~h}) \\
(10 \mathrm{~d})\end{array}$ & 12.5 & 33.0 & 40.0 & 1500 & 0.38 & N.S. & - & - & $\begin{array}{l}\text { Shi and } \mathrm{Yu} \text {, } \\
2006\end{array}$ \\
\hline $\begin{array}{l}\text { Rhodobacter strain } \\
8703\end{array}$ & Lactate & Batch & 131.0 & 151.0 & - & 50 & $\begin{array}{l}0.78- \\
0.96\end{array}$ & N.S. & & 10 & $\begin{array}{l}\text { Mao et al., } \\
1986\end{array}$ \\
\hline R. palustris R1 & Lactate & Batch & 9.1 & 82.7 & 12.6 & 150 & 0.11 & $\begin{array}{l}\text { Halogen and } \\
\text { tungsten }\end{array}$ & 102 & & $\begin{array}{l}\text { Barbosa et } \\
\text { al., } 2001\end{array}$ \\
\hline
\end{tabular}




\begin{tabular}{|c|c|c|c|c|c|c|c|c|c|c|c|}
\hline R. palustris R1 & Malate & Batch & 5.8 & 52.7 & 36.0 & 150 & 0.11 & $\begin{array}{l}\text { Halogen and } \\
\text { tungsten }\end{array}$ & 102 & & $\begin{array}{l}\text { Barbosa et } \\
\text { al., } 2001\end{array}$ \\
\hline R. palustris $\mathrm{R} 1$ & Butyrate & Batch & Nil & Nil & Nil & 150 & 0.11 & $\begin{array}{l}\text { Halogen and } \\
\text { tungsten }\end{array}$ & 102 & & $\begin{array}{l}\text { Barbosa et } \\
\text { al., } 2001\end{array}$ \\
\hline R. palustris $\mathrm{R} 1$ & Acetate & Batch & 2.2 & 20.0 & 14.8 & 150 & 0.11 & $\begin{array}{l}\text { Halogen and } \\
\text { tungsten }\end{array}$ & 102 & & $\begin{array}{l}\text { Barbosa et } \\
\text { al., } 2001\end{array}$ \\
\hline R. palustris & Acetate & Batch & 22.1 & - & - & - & $\begin{array}{l}1.23 \\
\mathrm{OD}_{660}\end{array}$ & N.S. & & $6-8$ & $\begin{array}{l}\text { Yang et al., } \\
2002\end{array}$ \\
\hline R. palustris $\mathrm{P} 4$ & Acetate & Batch & 1.6 & 9.8 & $\begin{array}{l}60.0- \\
70.0\end{array}$ & 50 & 0.17 & N.S. & & 2.5 & $\begin{array}{l}\text { Oh et al., } \\
2004\end{array}$ \\
\hline R. palustris WP3-5 & Acetate & Batch & 8.7 & 3.0 & 25.0 & 500 & 2.90 & halogen & 95 & & $\begin{array}{l}\text { Chen et al., } \\
2006\end{array}$ \\
\hline R. palustris WP3-5 & Acetate & Batch & 6.8 & 2.5 & 20.8 & 500 & 2.70 & $\begin{array}{l}\text { Optical fiber } \\
\text { and halogen }\end{array}$ & 95 & & $\begin{array}{l}\text { Chen et al., } \\
2006\end{array}$ \\
\hline R. palustris WP3-5 & Acetate & Batch & 17.1 & 9.5 & 49.5 & 500 & 1.80 & $\begin{array}{l}\text { Optical fiber } \\
\text { and halogen } \\
\text { and tungsten }\end{array}$ & 95 & & $\begin{array}{l}\text { Chen et al., } \\
2006\end{array}$ \\
\hline R. palustris WP3-5 & Butyrate & Batch & 24.9 & 28.4 & 57.4 & 100 & 0.88 & Tungsten & & 10 & $\begin{array}{l}\text { Chen et al., } \\
2007\end{array}$ \\
\hline R. rubrum & Lactate & $\begin{array}{l}\text { Continuous } \\
\text { (HRT 74h) }\end{array}$ & 65.0 & 20.0 & 64.5 & 1000 & $3.0-3.5$ & Tungsten & 300 & & $\begin{array}{l}\text { Zürrer and } \\
\text { Bachofen, } \\
1979 \\
\end{array}$ \\
\hline R. rubrum & Malate & Batch & 48.0 & - & 10.2 & 180 & - & Tungsten & & 10 & $\begin{array}{l}\text { Miyake et } \\
\text { al., } 1982\end{array}$ \\
\hline $\begin{array}{l}\text { Rubrivivax } \\
\text { gelatinosus SB24 }\end{array}$ & Starch & Batch & $7.8-11.3$ & $7.0-17.0$ & - & 23 & - & - & Nil & 10 & $\begin{array}{l}\text { Mahakhan } \\
\text { et al., 2005 } \\
\end{array}$ \\
\hline $\begin{array}{l}\text { Rhodopseudomonas } \\
\text { sp. HCC } 2037\end{array}$ & Lactate & Batch & 10.7 & 23.8 & 9.6 & 150 & 0.45 & $\begin{array}{l}\text { Halogen and } \\
\text { tungsten }\end{array}$ & 145 & & $\begin{array}{l}\text { Barbosa et } \\
\text { al., } 2001\end{array}$ \\
\hline $\begin{array}{l}\text { Rhodopseudomonas } \\
\text { sp. HCC } 2037\end{array}$ & Malate & Batch & 1.1 & 2.4 & 6.6 & 150 & 0.45 & $\begin{array}{l}\text { Halogen and } \\
\text { tungsten }\end{array}$ & 145 & & $\begin{array}{l}\text { Barbosa et } \\
\text { al., } 2001\end{array}$ \\
\hline $\begin{array}{l}\text { Rhodopseudomonas } \\
\text { sp. HCC } 2037\end{array}$ & Butyrate & Batch & 7.6 & 16.9 & 8.4 & 150 & 0.45 & $\begin{array}{l}\text { Halogen and } \\
\text { tungsten }\end{array}$ & 145 & & $\begin{array}{l}\text { Barbosa et } \\
\text { al., } 2001\end{array}$ \\
\hline
\end{tabular}




\begin{tabular}{|c|c|c|c|c|c|c|c|c|c|c|}
\hline $\begin{array}{l}\text { Rhodopseudomonas } \\
\text { sp. HCC } 2037\end{array}$ & Acetate & Batch & 25.2 & 56.0 & 72.8 & 150 & 0.45 & $\begin{array}{l}\text { Halogen and } \\
\text { tungsten }\end{array}$ & 145 & $\begin{array}{l}\text { Barbosa et } \\
\text { al., } 2001\end{array}$ \\
\hline $\begin{array}{l}\text { Rhodobium } \\
\text { marinum A-501 }\end{array}$ & Glucose & Batch & 5.3 & - & 7.2 & 65 & $\begin{array}{l}0.6 \\
\mathrm{OD}_{660} \\
\end{array}$ & Tungsten & 330 & $\begin{array}{l}\text { Ike et al., } \\
1999 \\
\end{array}$ \\
\hline $\begin{array}{l}\text { Rhodobium } \\
\text { marinum A-501 }\end{array}$ & Maltose & Batch & 3.3 & - & 4.5 & 65 & $\begin{array}{l}0.6 \\
\mathrm{OD}_{660} \\
\end{array}$ & Tungsten & 330 & $\begin{array}{l}\text { Ike et al., } \\
1999\end{array}$ \\
\hline $\begin{array}{l}\text { Rhodobium } \\
\text { marinum A-501 }\end{array}$ & Sucrose & Batch & 3.0 & - & 4.1 & 65 & $\begin{array}{l}0.6 \\
\mathrm{OD}_{660} \\
\end{array}$ & Tungsten & 330 & $\begin{array}{l}\text { Ike et al., } \\
1999\end{array}$ \\
\hline $\begin{array}{l}\text { Rhodobium } \\
\text { marinum A-501 }\end{array}$ & Lactate & Batch & 9.1 & - & 12.4 & 65 & $\begin{array}{l}0.6 \\
\mathrm{OD}_{660} \\
\end{array}$ & Tungsten & 330 & $\begin{array}{l}\text { Ike et al., } \\
1999\end{array}$ \\
\hline $\begin{array}{l}\text { Rhodobium } \\
\text { marinum A-501 }\end{array}$ & Malate & Batch & 5.7 & - & 7.8 & 65 & $\begin{array}{l}0.6 \\
\mathrm{OD}_{660} \\
\end{array}$ & Tungsten & 330 & $\begin{array}{l}\text { Ike et al., } \\
1999 \\
\end{array}$ \\
\hline $\begin{array}{l}\text { Rhodobium } \\
\text { marinum A-501 }\end{array}$ & $\begin{array}{l}\text { Lactate +algal } \\
\text { extract }\end{array}$ & Batch & 68.6 & 114.0 & 47.9 & 65 & 0.60 & Tungsten & 330 & $\begin{array}{l}\text { Kawaguchi } \\
\text { et al., } 2002 \\
\end{array}$ \\
\hline $\begin{array}{l}\text { Rhodobium } \\
\text { marinum A-501 }\end{array}$ & Lactate & Batch & 26.5 & 44.2 & 29.2 & 65 & 0.60 & Tungsten & 330 & $\begin{array}{l}\text { Kawaguchi } \\
\text { et al., } 2002 \\
\end{array}$ \\
\hline $\begin{array}{l}\text { Rhodovulum sp. } \\
\text { NKPB160471R }\end{array}$ & Malate & Batch & 713.0 & 230.0 & - & 12 & 3.10 & Fluorescent & 1800 & $\begin{array}{l}\text { Matsunaga } \\
\text { et al., } 2000 \\
\end{array}$ \\
\hline $\begin{array}{l}\text { Rhodovulum sp. } \\
\text { NKPB160471R }\end{array}$ & Malate & $\begin{array}{l}\text { Semi-batch } \\
\text { (Micro- } \\
\text { aerobic) } \\
(150 \mathrm{~h}) \\
\end{array}$ & $26.7-31$ & $8.6-10.0$ & - & 500 & 3.10 & Fluorescent & 34.5 & $\begin{array}{l}\text { Matsunaga } \\
\text { et al., } 2000\end{array}$ \\
\hline $\begin{array}{l}\text { Rhodovulum } \\
\text { sulfidophilum WT }\end{array}$ & PHB & Batch & 33.0 & - & - & 190 & $\begin{array}{l}6.85 \\
\mathrm{OD}_{660} \\
\end{array}$ & Incandescent & 190 & $\begin{array}{l}\text { Maeda et } \\
\text { al., } 2003\end{array}$ \\
\hline
\end{tabular}


Table 2. Hydrogen production by suspended cells of the mixed culture of PHP bacteria

\begin{tabular}{|c|c|c|c|c|c|c|c|c|c|c|}
\hline Organisms & Substrates & $\begin{array}{l}\text { Reactor } \\
\text { type }\end{array}$ & $\begin{array}{l}\operatorname{Max} . \mathrm{H}_{2} \\
\operatorname{rate}(\mathrm{ml} / \mathrm{l} / \mathrm{h})\end{array}$ & $\begin{array}{l}\operatorname{Max} . \mathrm{H}_{2} \\
\text { rate } \\
(\mathrm{ml} / \mathrm{g} / \mathrm{h})\end{array}$ & $\begin{array}{l}\text { Yield } \\
(\%)\end{array}$ & $\begin{array}{l}\text { Culture } \\
\text { volume } \\
(\mathrm{ml})\end{array}$ & $\begin{array}{l}\text { Cell } \\
\text { density } \\
(\mathrm{g} / \mathrm{l})\end{array}$ & $\begin{array}{l}\text { Light } \\
\text { source }\end{array}$ & $\begin{array}{l}\text { Light } \\
\text { intensity } \\
\left(\mathrm{W} / \mathrm{m}^{2}\right)\end{array}$ & Reference \\
\hline $\begin{array}{l}\text { Mixed culture } \\
\text { Sludge } B C 1\end{array}$ & Starch & Batch & 9.6 & - & 13.0 & 65 & $0.6 \mathrm{OD}_{660}$ & Tungsten & 330 & $\begin{array}{l}\text { Ike et al., } \\
1999\end{array}$ \\
\hline $\begin{array}{l}\text { Mixed culture } \\
\text { Sludge BC1 }\end{array}$ & Glucose & Batch & 4.9 & - & 6.6 & 65 & $0.6 \mathrm{OD}_{660}$ & Tungsten & 330 & $\begin{array}{l}\text { Ike et al., } \\
1999\end{array}$ \\
\hline $\begin{array}{l}\text { Mixed culture } \\
\text { Sludge BC1 }\end{array}$ & Maltose & Batch & 4.3 & - & 5.9 & 65 & $0.6 \mathrm{OD}_{660}$ & Tungsten & 330 & $\begin{array}{l}\text { Ike et al., } \\
1999\end{array}$ \\
\hline $\begin{array}{l}\text { Mixed culture } \\
\text { Sludge BC1 } \\
\end{array}$ & Cellobiose & Batch & 5.3 & - & 7.2 & 65 & $0.6 \mathrm{OD}_{660}$ & Tungsten & 330 & $\begin{array}{l}\text { Ike et al., } \\
1999\end{array}$ \\
\hline $\begin{array}{l}\text { Mixed culture } \\
\text { Sludge BC1 }\end{array}$ & Sucrose & Batch & 4.5 & - & 6.1 & 65 & $0.6 \mathrm{OD}_{660}$ & Tungsten & 330 & $\begin{array}{l}\text { Ike et al., } \\
1999\end{array}$ \\
\hline $\begin{array}{l}\text { Mixed culture } \\
\text { Sludge BC1 }\end{array}$ & Acetate & Batch & 13.7 & - & 18.7 & 65 & $0.6 \mathrm{OD}_{660}$ & Tungsten & 330 & $\begin{array}{l}\text { Ike et al., } \\
1999 \\
\end{array}$ \\
\hline $\begin{array}{l}\text { Mixed culture } \\
\text { Sludge BC1 }\end{array}$ & Lactate & Batch & 20.3 & - & 27.6 & 65 & $0.6 \mathrm{OD}_{660}$ & Tungsten & 330 & $\begin{array}{l}\text { Ike et al., } \\
1999\end{array}$ \\
\hline $\begin{array}{l}\text { Mixed culture } \\
\text { Sludge BC1 }\end{array}$ & Malate & Batch & 6.5 & - & 8.8 & 65 & $0.6 \mathrm{OD}_{660}$ & Tungsten & 330 & $\begin{array}{l}\text { Ike et al., } \\
1999 \\
\end{array}$ \\
\hline $\begin{array}{l}\text { Mixed culture } \\
\text { Sludge BC1 }\end{array}$ & Glycerol & Batch & 3.9 & - & 5.3 & 65 & $0.6 \mathrm{OD}_{660}$ & Tungsten & 330 & $\begin{array}{l}\text { Ike et al., } \\
1999\end{array}$ \\
\hline $\begin{array}{l}\text { Mixed phototrophic } \\
\text { sludge culture }\end{array}$ & $\begin{array}{l}\text { Synthetic } \\
\text { wastewater } \\
\text { (acetate + butyrate+ } \\
\text { ethanol) }\end{array}$ & $\begin{array}{l}\text { Continuous } \\
\text { (HRT 25h) } \\
(30 \mathrm{~d})\end{array}$ & 17.4 & 5.6 & 12.0 & 450 & 3.10 & Tungsten & $90-150$ & $\begin{array}{l}\text { Zhang et al., } \\
2002\end{array}$ \\
\hline $\begin{array}{l}\text { Mixed phototrophic } \\
\text { sludge culture }\end{array}$ & Acetate & Batch & 6.7 & 16.8 & 62.5 & 100 & 0.40 & Tungsten & 200 & $\begin{array}{l}\text { Fang et al., } \\
2005\end{array}$ \\
\hline $\begin{array}{l}\text { Mixed phototrophic } \\
\text { sludge culture }\end{array}$ & Butyrate & Batch & 5.3 & 13.2 & 37.0 & 100 & 0.40 & Tungsten & 200 & $\begin{array}{l}\text { Fang et al., } \\
2005\end{array}$ \\
\hline $\begin{array}{l}\text { Mixed culture of } \\
\text { PSB }\end{array}$ & $\begin{array}{l}\text { Acetate + propionate } \\
\text { + butyrate }\end{array}$ & Batch & 4.0 & 5.2 & 22.0 & - & 0.77 & Blue light & - & $\begin{array}{l}\text { Takabatake et } \\
\text { al., } 2004\end{array}$ \\
\hline
\end{tabular}


Table 3. Hydrogen production by co-culture of PHP bacteria with other bacteria*

\begin{tabular}{|c|c|c|c|c|c|c|c|c|c|c|}
\hline \multicolumn{2}{|l|}{ Organisms } & \multirow[t]{2}{*}{ Substrates } & \multirow{2}{*}{$\begin{array}{l}\text { Max. } \\
\mathrm{H}_{2} \text { rate } \\
(\mathrm{ml} / \mathrm{l} / \mathrm{h})\end{array}$} & \multirow[t]{2}{*}{$\begin{array}{l}\text { Yield } \\
(\%)\end{array}$} & \multirow{2}{*}{$\begin{array}{l}\text { Culture } \\
\text { volume } \\
(\mathrm{ml})\end{array}$} & \multirow{2}{*}{$\begin{array}{l}\text { Cell density } \\
(\mathrm{g} / 1) \\
\left(\mathrm{PHP} / \mathrm{FB}^{\#}\right)\end{array}$} & \multirow[t]{2}{*}{ Light source } & \multicolumn{2}{|c|}{$\begin{array}{l}\text { Light } \\
\text { intensity }\end{array}$} & \multirow[t]{2}{*}{ Reference } \\
\hline PSB & $\begin{array}{l}\text { Fermentative } \\
\text { bacteria }\end{array}$ & & & & & & & $\mathrm{W} / \mathrm{m}^{2}$ & klux & \\
\hline R. capsulatus B100 & $\begin{array}{l}\text { Cellulomonas sp. } \\
\text { ATCC } 21399\end{array}$ & Cellulose & - & 35.8 & 20 & - & Incandescent & - & - & $\begin{array}{l}\text { Odom and Wall, } \\
1983\end{array}$ \\
\hline $\begin{array}{l}\text { R. capsulatus ST410 } \\
\text { (Hup }{ }^{-} \text {mutant) }\end{array}$ & $\begin{array}{l}\text { Cellulomonas sp. } \\
\text { ATCC } 21399\end{array}$ & Cellulose & - & 51.7 & 20 & - & Incandescent & - & - & $\begin{array}{l}\text { Odom and Wall, } \\
1983\end{array}$ \\
\hline $\begin{array}{l}\text { R. sphaeroides RV } \\
\text { (co-immobilization) }\end{array}$ & $\begin{array}{l}\text { Clostridium } \\
\text { butyricum IFO } \\
3847\end{array}$ & Glucose & 41.0 & 4.1 & 200 & $1.5 / 1.3$ & Tungsten & & 8.5 & Zhu et al., 2001 \\
\hline $\begin{array}{l}\text { R. sphaeroides RV } \\
\text { (co-immobilization) }\end{array}$ & $\begin{array}{l}\text { Clostridium } \\
\text { butyricum IFO } \\
3847\end{array}$ & $\begin{array}{l}\text { Tofu } \\
\text { wastewater }\end{array}$ & 14.9 & - & 200 & $1.9 / 1.7$ & Tungsten & & 8.5 & Zhu et al., 2002 \\
\hline $\begin{array}{l}\text { R. sphaeroides } \\
\text { O.U.001 }\end{array}$ & $\begin{array}{l}\text { Halobacterium } \\
\text { salinarum S9 }\end{array}$ & Malate & 27.0 & - & 400 & - & Tungsten & 150 & & Zabut et al., 2006 \\
\hline $\begin{array}{l}\text { Rhodobium } \\
\text { marinum A-501 }\end{array}$ & $\begin{array}{l}\text { Vibrio fluvialis T- } \\
522\end{array}$ & Algal starch & 8.6 & 52.0 & 65 & - & Tungsten & 330 & & Ike et al., 1999 \\
\hline $\begin{array}{l}\text { Rhodobium } \\
\text { marinum A-501 }\end{array}$ & $\begin{array}{l}\text { Lactobacillus } \\
\text { amylovorus }\end{array}$ & $\begin{array}{l}\text { Algal starch in } \\
\text { D. tertiolecta }\end{array}$ & 38.0 & 60.8 & 65 & $0.6 / 0.5$ & Tungsten & 330 & & $\begin{array}{l}\text { Kawaguchi et al., } \\
2001\end{array}$ \\
\hline $\begin{array}{l}\text { Rhodobium } \\
\text { marinum A-501 }\end{array}$ & $\begin{array}{l}\text { Lactobacillus } \\
\text { amylovorus }\end{array}$ & $\begin{array}{l}\text { Algal starch in } \\
\text { C. reinhardtii }\end{array}$ & 20.8 & 52.3 & 65 & $0.6 / 0.5$ & Tungsten & 330 & & $\begin{array}{l}\text { Kawaguchi et al., } \\
2001\end{array}$ \\
\hline
\end{tabular}

*All studies were in batch.

\# FB: Fermentative bacteria or other bacteria 
Table 4. Hydrogen production by immobilized cultures of PHP bacteria

\begin{tabular}{|c|c|c|c|c|c|c|c|c|c|c|c|}
\hline \multirow[t]{2}{*}{ Organisms } & \multirow[t]{2}{*}{$\begin{array}{l}\text { Support } \\
\text { materials }\end{array}$} & \multirow[t]{2}{*}{ Substrates } & \multirow[t]{2}{*}{$\begin{array}{l}\text { Reactor } \\
\text { type }\end{array}$} & \multirow{2}{*}{$\begin{array}{l}\text { Max. } \\
\mathrm{H}_{2} \text { rate } \\
(\mathrm{ml} / \\
\left.\mathrm{cm}^{2} / \mathrm{h}\right) \\
\end{array}$} & \multirow{2}{*}{$\begin{array}{l}\text { Max. } \\
\mathrm{H}_{2} \text { rate } \\
(\mathrm{ml} / \mathrm{l} / \mathrm{h})\end{array}$} & \multirow{2}{*}{$\begin{array}{l}\text { Max. } H_{2} \\
\text { rate } \\
(\mathrm{ml} / \mathrm{g} / \mathrm{h})\end{array}$} & \multirow[t]{2}{*}{$\begin{array}{l}\text { Yield } \\
(\%)\end{array}$} & \multirow{2}{*}{$\begin{array}{l}\text { Culture } \\
\text { volume } \\
(\mathrm{ml})\end{array}$} & \multirow{2}{*}{$\begin{array}{l}\text { Cell } \\
\text { density } \\
(\mathrm{g} / \mathrm{l})\end{array}$} & $\begin{array}{l}\text { Light } \\
\text { intensity }\end{array}$ & \multirow[t]{2}{*}{ Reference } \\
\hline & & & & & & & & & & $\mathrm{W} / \mathrm{m}^{2} \quad$ klux & \\
\hline $\begin{array}{l}\text { Rhodopseudomonas } \\
\text { strain } 2604\end{array}$ & $2 \%$ agar & Butyrate & Batch & 0.26 & 87.4 & 510 & 67.0 & 70 & $0.7-1.0$ & 10 & $\begin{array}{l}\text { Mao et al., } \\
1986\end{array}$ \\
\hline $\begin{array}{l}\text { Rhodopseudomonas } \\
\text { strain } 2613\end{array}$ & $2 \%$ agar & Acetate & Batch & 0.25 & 86.7 & 506 & 67.0 & 70 & $0.7-1.0$ & 10 & $\begin{array}{l}\text { Mao et al., } \\
1986\end{array}$ \\
\hline $\begin{array}{l}\text { Rhodopseudomonas } \\
\text { strain } 2613\end{array}$ & $2 \%$ agar & $\begin{array}{l}\text { Mixture of } \\
\text { acetate, } \\
\text { butyrate \& } \\
\text { lactate }\end{array}$ & Batch & 0.34 & 115.2 & 672 & 64.0 & 70 & $0.7-1.0$ & 10 & $\begin{array}{l}\text { Mao et al., } \\
1986\end{array}$ \\
\hline $\begin{array}{l}\text { Rhodopseudomonas } \\
\text { strain } 2806\end{array}$ & $2 \%$ agar & Lactate & Batch & 0.24 & 81.6 & 476 & 71.0 & 70 & $0.7-1.0$ & 10 & $\begin{array}{l}\text { Mao et al., } \\
1986\end{array}$ \\
\hline $\begin{array}{l}\text { Rhodobacter strain } \\
8703\end{array}$ & $2 \%$ agar & Butyrate & Batch & 0.32 & 110.1 & 642 & 67.0 & 70 & $0.7-1.0$ & 10 & $\begin{array}{l}\text { Mao et al., } \\
1986\end{array}$ \\
\hline $\begin{array}{l}\text { Rhodobacter strain } \\
8703\end{array}$ & $2 \%$ agar & Lactate & Batch & 0.35 & 119.3 & 696 & 77.0 & 70 & $0.7-1.0$ & 10 & $\begin{array}{l}\text { Mao et al., } \\
1986 \\
\end{array}$ \\
\hline $\begin{array}{l}\text { Rhodobacter strain } \\
8703\end{array}$ & $2 \%$ agar & $\begin{array}{l}\text { Mixture of } \\
\text { acetate, } \\
\text { butyrate \& } \\
\text { lactate }\end{array}$ & Batch & 0.23 & 79.2 & 462 & 53.0 & 70 & $0.7-1.0$ & 10 & $\begin{array}{l}\text { Mao et al., } \\
1986\end{array}$ \\
\hline R. sphaeroides RV & $2 \%$ agar & $\begin{array}{l}\text { Tofu } \\
\text { wastewater }\end{array}$ & Batch & 0.21 & 78.8 & 597 & 15.0 & 200 & 0.66 & 8 & $\begin{array}{l}\text { Zhu et al., } \\
1999 \text { a }\end{array}$ \\
\hline R. sphaeroides RV & $2 \%$ agar & Glucose & Batch & 0.14 & 50.0 & 167 & 13.6 & 200 & 1.5 & 8.5 & $\begin{array}{l}\text { Zhu et al., } \\
2001\end{array}$ \\
\hline R. sphaeroides RV & $2 \%$ agar & $\begin{array}{l}\text { Tofu } \\
\text { wastewater }\end{array}$ & Batch & 0.20 & 74.7 & 393 & - & 200 & 1.9 & 8.5 & $\begin{array}{l}\text { Zhu et al., } \\
2002\end{array}$ \\
\hline R. sphaeroides RV & $\begin{array}{l}1 \% \text { chitosan } \\
+2 \% \text { agar } \\
\end{array}$ & Lactate & Batch & 0.24 & 90.0 & 180 & 36.0 & 200 & 2.5 & 8.5 & $\begin{array}{l}\text { Zhu et al., } \\
1999 \text { b }\end{array}$ \\
\hline
\end{tabular}




\begin{tabular}{|c|c|c|c|c|c|c|c|c|c|c|c|c|}
\hline R. sphaeroides RV & $\begin{array}{l}0.5 \% \\
\text { chitosan }+ \\
2 \% \text { agar }\end{array}$ & Lactate & Batch & 0.23 & 85.0 & 170 & 34.0 & 200 & 2.5 & & 8.5 & $\begin{array}{l}\text { Zhu et al., } \\
1999 \text { b }\end{array}$ \\
\hline R. sphaeroides RV & $2 \%$ agar & Lactate & Batch & 0.19 & 70.0 & 140 & 25.0 & 200 & 2.5 & & 8.5 & $\begin{array}{l}\text { Zhu et al., } \\
1999 \text { b }\end{array}$ \\
\hline R. sphaeroides RV & Porous glass & Succinate & Continuous & 0.065 & 310.0 & - & 55.0 & - & 11.2 & 300 & & $\begin{array}{l}\text { Tsygankov } \\
\text { et al., } 1994\end{array}$ \\
\hline $\begin{array}{l}\text { R. sphaeroides } \\
\text { GL-1 }\end{array}$ & $\begin{array}{l}\text { Polyurethane } \\
\text { foam }\end{array}$ & Lactate & $\begin{array}{l}\text { Continuous } \\
\text { (HRT } 43.5 \\
\text { h) }(35 \mathrm{~d})\end{array}$ & 0.17 & 210.0 & - & 86.0 & 200 & - & 300 & & $\begin{array}{l}\text { Fedorov et } \\
\text { al., } 1998\end{array}$ \\
\hline $\begin{array}{l}\text { R. palustris DSM } \\
131\end{array}$ & $\begin{array}{l}\text { Sodium } \\
\text { alginate ( } 50 \\
\mu \mathrm{m} \text { bead })\end{array}$ & Benzoate & Batch & - & 112.0 & 6.7 & 88.0 & 30 & 10.0 & & 10 & $\begin{array}{l}\text { Fißler et al., } \\
1995\end{array}$ \\
\hline $\begin{array}{l}\text { R. palustris DSM } \\
131\end{array}$ & $\begin{array}{l}\text { Sodium } \\
\text { alginate ( } 50 \\
\mu \mathrm{m} \text { bead })\end{array}$ & Cinnamate & Batch & - & 127.0 & 7.6 & 86.0 & 30 & 10.0 & & 10 & $\begin{array}{l}\text { Fißler et al., } \\
1995\end{array}$ \\
\hline $\begin{array}{l}\text { R. palustris DSM } \\
131\end{array}$ & $\begin{array}{l}\text { Sodium } \\
\text { alginate ( } 50 \\
\mu \mathrm{m} \text { bead })\end{array}$ & Mandelate & Batch & - & 71.7 & 4.3 & 60.0 & 30 & 10.0 & & 10 & $\begin{array}{l}\text { Fißler et al., } \\
1995\end{array}$ \\
\hline $\begin{array}{l}\text { R. palustris DSM } \\
131\end{array}$ & $\begin{array}{l}\text { Sodium } \\
\text { alginate ( } 50 \\
\mu \mathrm{m} \text { bead })\end{array}$ & Benzoylformate & Batch & - & 65.0 & 3.9 & 57.0 & 30 & 10.0 & & 10 & $\begin{array}{l}\text { Fißler et al., } \\
1995\end{array}$ \\
\hline
\end{tabular}


Table 5. Hydrogen production by mutants of PHP bacteria*

\begin{tabular}{|c|c|c|c|c|c|c|c|c|c|c|}
\hline \multirow[t]{2}{*}{ Organisms } & \multirow[t]{2}{*}{ Substrates } & \multirow{2}{*}{$\begin{array}{l}\text { Max. } \mathrm{H}_{2} \\
\text { rate } \\
(\mathrm{ml} / \mathrm{l} / \mathrm{h})\end{array}$} & \multirow{2}{*}{$\begin{array}{l}\text { Max. } \mathrm{H}_{2} \\
\text { rate } \\
(\mathrm{ml} / \mathrm{g} / \mathrm{h})\end{array}$} & \multirow{2}{*}{$\begin{array}{l}\text { Yield } \\
(\%)\end{array}$} & \multirow{2}{*}{$\begin{array}{l}\text { Culture } \\
\text { volume (ml) }\end{array}$} & \multirow{2}{*}{$\begin{array}{l}\text { Cell density } \\
(\mathrm{g} / \mathrm{l})\end{array}$} & \multirow[t]{2}{*}{ Light source } & \multicolumn{2}{|c|}{ Light intensity } & \multirow[t]{2}{*}{ Reference } \\
\hline & & & & & & & & $\mathrm{W} / \mathrm{m}^{2}$ & klux & \\
\hline $\begin{array}{l}\text { R. sphaeroides } \mathrm{P} 3 \\
\text { (mutant of } \mathrm{RV} \text { ) }\end{array}$ & Lactate & - & - & - & 2 & 1.0 & $\begin{array}{l}\text { Halogen }(800 \\
\text { and } 850 \mathrm{~nm})\end{array}$ & 80 & & $\begin{array}{l}\text { Vasilyeva et al., } \\
1999\end{array}$ \\
\hline $\begin{array}{l}\text { R. sphaeroides MTP4 } \\
\text { (Reduced pigment } \\
\text { mutant of RV) }\end{array}$ & Lactate & 46.0 & 100.0 & 40.0 & 165 & 0.46 & Tungsten & 300 & & $\begin{array}{l}\text { Kondo et al., } \\
2002 \mathrm{a}\end{array}$ \\
\hline $\begin{array}{l}\text { R. sphaeroides MTP4 } \\
\text { (Reduced pigment } \\
\text { mutant of RV) }\end{array}$ & Lactate & 21.2 & 35.4 & - & 800 & 0.60 & Tungsten & 300 & & Kondo et al., 2006 \\
\hline $\begin{array}{l}\text { R. sphaeroides KD131 } \\
\text { Hup }^{-} / \mathrm{Phb}^{-} \text {mutant }\end{array}$ & Malate & 45.8 & - & 49.9 & 50 & $2.9 \mathrm{OD}_{660}$ & Halogen & & 8 & Kim et al., 2004 \\
\hline $\begin{array}{l}\text { R. sphaeroides KD131 } \\
\text { Hup }^{-} / \mathrm{Phb}^{-} \text {mutant }\end{array}$ & Lactate & 25.0 & - & 27.2 & 50 & $1.8 \mathrm{OD}_{660}$ & Halogen & & 8 & Kim et al., 2004 \\
\hline $\begin{array}{l}\text { R. sphaeroides KD131 } \\
\text { Hup }^{-} / \mathrm{Phb}^{-} \text {mutant }\end{array}$ & Acetate & 7.7 & - & 12.6 & 50 & $1.4 \mathrm{OD}_{660}$ & Halogen & & 8 & Kim et al., 2004 \\
\hline $\begin{array}{l}\text { R. sphaeroides KD131 } \\
\text { Hup } / \text { Phb }^{-} \text {mutant }\end{array}$ & Glucose & 12.4 & - & 6.7 & 50 & $1.9 \mathrm{OD}_{660}$ & Halogen & & 8 & Kim et al., 2004 \\
\hline $\begin{array}{l}\text { R. capsulatus B10S } \\
\text { Hup mutant }\end{array}$ & N.S. & 94.1 & - & - & 1 & $2 \mathrm{OD}_{600}$ & N.S. & - & - & Krahn et al., 1996 \\
\hline $\begin{array}{l}\text { R. capsulatus ST-410 } \\
\text { (Hup mutant of B100) }\end{array}$ & Malate & 100.0 & 140.0 & 68.0 & 5 & - & Tungsten & & 6.6 & $\begin{array}{l}\text { Ooshima et al., } \\
1998\end{array}$ \\
\hline $\begin{array}{l}\text { R. capsulatus ST-410 } \\
\text { (Hup mutant of B100) }\end{array}$ & Acetate & 41.0 & - & 84.0 & 5 & - & Tungsten & & 6 & $\begin{array}{l}\text { Ooshima et al., } \\
1998\end{array}$ \\
\hline $\begin{array}{l}\text { R. capsulatus ST- } 410 \\
\text { (Hup mutant) }\end{array}$ & Malate & 59.0 & 107.0 & 8.1 & 550 & 0.55 & Tungsten & 60 & & $\begin{array}{l}\text { Katsuda et al., } \\
2000\end{array}$ \\
\hline
\end{tabular}

\footnotetext{
*All studies were in batch.
} 